\title{
A risk assessment tool for contaminated sites in low-permeability fractured media
}

\author{
Chambon, Julie Claire Claudia; Binning, Philip John; Jørgensen, Peter R.; Bjerg, Poul Løgstrup
}

Published in:

Journal of Contaminant Hydrology

Link to article, DOI:

10.1016/j.jconhyd.2011.03.001

Publication date:

2011

Link back to DTU Orbit

Citation (APA):

Chambon, J. C. C., Binning, P. J., Jørgensen, P. R., \& Bjerg, P. L. (2011). A risk assessment tool for

contaminated sites in low-permeability fractured media. Journal of Contaminant Hydrology, 124(1-4), 82-98. https://doi.org/10.1016/j.jconhyd.2011.03.001

\section{General rights}

Copyright and moral rights for the publications made accessible in the public portal are retained by the authors and/or other copyright owners and it is a condition of accessing publications that users recognise and abide by the legal requirements associated with these rights.

- Users may download and print one copy of any publication from the public portal for the purpose of private study or research.

- You may not further distribute the material or use it for any profit-making activity or commercial gain

- You may freely distribute the URL identifying the publication in the public portal 


\section{A risk assessment tool for contaminated sites in low- permeability fractured media}

Julie C. Chambon*a, Philip J. Binning ${ }^{\mathrm{a}}$, Peter R. Jørgensen ${ }^{\mathrm{b}}$ and Poul L. Bjerg ${ }^{\mathrm{a}}$

${ }^{a}$ Department of Environmental Engineering, Technical University of Denmark, Miljoevej, Building 113, 2800 Kgs. Lyngby, Denmark.

${ }^{\mathrm{b}}$ GEO Maglebjervej 1, 2800 Kgs. Lyngby, Denmark

*Corresponding author. Department of Environmental Engineering, Technical University of Denmark, Miljoevej, Building 113, 2800 Kgs. Lyngby, Denmark; Tel.: +45 4525 2169; Fax: +45 4593 2850; E-mail: jccc@env.dtu.dk

Submitted to Journal of Contaminant Hydrology, $1^{\text {st }}$ August 2010 


\section{Abstract}

A risk assessment tool for contaminated sites in low-permeability fractured media is developed, based on simple transient and steady-state analytical solutions. The Discrete Fracture (DF) tool, which explicitly accounts for the transport along fractures, covers different source geometries and history and can be applied to a wide range of compounds. The tool successfully simulates published data from short duration column and field experiments. The use for risk assessment is illustrated by three typical risk assessment case studies, involving pesticides, chlorinated solvents, benzene and MTBE. The model is compared with field data and with results from a simpler approach based on an Equivalent Porous Media (EPM). Risk assessment conclusions of the DF and EPM approaches are very different due to the early breakthrough, long term tailing, and lower attenuation due to degradation associated with fractured media. While the DF tool simulates the field data, it is difficult to conclude that the DF model is superior to an EPM model because of a lack of long term monitoring data. However, better agreement with existing field data by the DF model using observed physical fracture parameters favors the use of this model over the EPM model for risk assessments.

Keywords: risk assessment; fractured media; analytical solutions; discrete fracture; Equivalent Porous Media

\section{Introduction}

Many contaminated sites occur in areas with low-permeability fractured media (such as clay-rich glacial deposits) at the land surface. Fractured media are important to consider when assessing risk to the groundwater at contaminated sites, because of the fast downward pathway along the fractures and the diffusion into the porous matrix. The porous matrix can 
act as a long term secondary source that leaches through back diffusion to the fractures and the underlying aquifer (Parker et al., 2008). However, in most screening tools for risk assessment (e.g., ROME (ANPA, 2002), BIOBALANCE (Kamath, 2006), RISC4 (Spence, 2001), CatchRisk (Troldborg et al., 2008)), fractures are not explicitly considered and instead are represented by an equivalent porous media (EPM) with equivalent hydraulic conductivity and porosity. Although such simplifications can be relevant in some cases, particularly for small fracture spacings (typically between 1 and $40 \mathrm{~cm}$ ) (McKay et al., 1997; Pankow et al., 1986; van der Kamp, 1992), transport processes causing fast breakthrough and the large storage capacity of low-permeability fractured media are generally not well represented. The migration of contaminants is controlled by advection in the fracture, exchange between the fracture and the matrix and molecular diffusion in the low-permeability matrix. In addition degradation processes for organic contaminants add to the complexity. Many studies have shown that these phenomena cannot be properly modeled by an EPM approach and require the use of discrete fracture models (DF) (e.g. Jørgensen et al., 1998; Sidle et al., 1998).

Fracture networks can be very complex and many numerical models have been developed to simulate flow and contaminant transport in such systems (e.g., Chambon et al., 2010; Slough et al., 1999; Sudicky and McLaren, 1992; Therrien and Sudicky, 1996). However in a regulatory context for risk assessment of contaminated sites, simple screening models with limited data demand are often necessary. Therefore analytical solutions that include the main processes but are not too data demanding are preferable.

Many analytical solutions are available for simulating contaminant transport in a single or parallel fractures system, accounting for advection and dispersion along the fracture, molecular diffusion and sorption within the matrix, as well as first order radioactive decay in both the fracture and matrix (e.g., Shih, 2007; Sudicky and Frind, 1982; Tang et al., 1981). However, the available solutions do not consider the range of initial and boundary conditions 
required for risk assessment (constant source, source removal and contaminant trapped in the fractured media). They are also not coupled to an underlying groundwater system, which is required for risk assessment applications. In the current work/study the solution of Tang et al. (1981) is modified to include the required conditions. The full set of analytical solutions for the risk assessment model is presented in a user-friendly Microsoft Excel spreadsheet to enable use by non-specialist.

The modification of published analytical solutions is fairly straight forward and so the main contribution of this paper is the demonstration of the use of the solutions for risk assessment and comparison with observed data for a number of typical risk assessment cases. The validity of risk assessment models is generally difficult to document because of the lack of appropriate (long-term, over decades - centuries) observed data for comparison (e.g. Fischer et al., 2010; Kohne et al., 2009; Tait et al., 2004b; Troldborg et al., 2008). Models for flow and transport through low-permeability fractured media have been compared with column and field data of short duration (typically hours to days, e.g. Jørgensen et al., 1998; 2002; McKay et al., 1993b), but the long term leaching due to slow back diffusion from the matrix to the fracture system has not been documented because of the long timeframes. In this study, the developed tool is compared to controlled experimental data and to field data from real case studies and the suitability of the models for risk assessment is discussed. Finally, the developed DF model is compared with EPM model using datasets from three cases studies and the applicability of each tool for risk assessment in fractured media is discussed.

\section{Conceptual models}

The physical system is illustrated in Figure 1a with a low-permeability fractured media overlying an aquifer. The developed risk assessment tool focuses on fully saturated fractured media, and transport of gas phase is not considered. This is a realistic assumption, as the lowpermeability matrix will retain water and will usually be fully saturated even when above the 
water table, and so gas transport is limited to fracture zones and is negligible. The real fracture network is simplified in Fig. 1b, so that only fully penetrating vertical fractures are considered and a homogeneous fracture spacing is assumed. These simplifications of the natural network are motivated by the scope of this study, which focuses on downward transport from fractured media to the aquifer, so the horizontal features are of less importance. Although some analytical solutions exist for the case of parallel fractures, they are quite complex and numerical integration is required. For risk assessment purposes, simple computational approaches which can be implemented in spreadsheets, GIS etc are preferred. Therefore the geometry is further simplified to consider only a single fracture surrounded by a semi-infinite matrix. For large fracture spacings $(2 \mathrm{~B}>1-1.5 \mathrm{~m})$, this simplification is reasonable (see Supplementary information).

Fig. 1. a) Physical system considered in this study: a low-permeability fractured media overlies an aquifer. The area of interest is shown with the dashed box. b) Simplification of the fractured media for modeling: the fractures are assumed to be fully penetrating and equally spaced. c) Further simplification with the case of a single fracture embedded in a semi-infinite porous matrix.

Based on this physical system, the risk assessment tool is developed with three conceptual models for the source geometry and history. Model 1 represents the source overlying the fractured media, with a constant concentration, for either a known duration (model 1a in Fig. 2), for example an underground storage tank that has been removed, or for infinite time (model $1 \mathrm{~b}$ in Fig. 2). In model 2 the source has been removed, but contaminant trapped in the clay below the former source continues to leach for many years afterwards (model 2 in Fig. 2). This case can be approximated with a zero input concentration at the top of the fracture and a homogeneous initial concentration in the porous matrix. Model 2 is useful when the history of contamination (amount, length, concentration, geometry) of the fractured media is 
unknown and the only available data are the measured concentrations in the porous matrix.

Fig. 2. Conceptual sketch of the three models (top). Model $1 \mathrm{a}$ and $1 \mathrm{~b}$ represent a source overlying the fractured media, for a years in case of model 1a and for infinite time in case of model 1b. Model 2 represents the case of contaminant trapped uniformly in the porous matrix.

\section{$4 \quad$ Mathematical model}

The conceptual models have the same physical settings and only the boundary and initial conditions change. The mathematical model is based on the following set of assumptions: (i) the system is fully saturated (ii) linear reversible and instantaneous equilibrium partitioning between dissolved and sorbed phases, (iii) mass transport along the fracture is onedimensional (iv) dispersion along the fracture is neglected, (v) advection in the porous matrix is neglected, (vi) transport in the matrix is perpendicular to the fracture, (vii) degradation can be described as a first-order process and only occurs in the water phase, (viii) degradation products are not considered and (viii) separate liquid phase transport is not included.

\subsection{Governing equations}

The one-dimensional transport equation in a vertical fracture is, under the assumptions above (Tang et al., 1981):

$$
\mathrm{R}_{\mathrm{f}} \frac{\partial \mathrm{C}_{\mathrm{f}}}{\partial \mathrm{t}}+\mathrm{v}_{\mathrm{f}} \frac{\partial \mathrm{C}_{\mathrm{f}}}{\partial \mathrm{z}}+\frac{\mathrm{Q}_{\mathrm{m}}}{\mathrm{b}}+\lambda \mathrm{C}_{\mathrm{f}}=0
$$

where $C_{f}$ is the solute aqueous concentration in the fracture $\left(M / L^{3}\right), R_{f}$ is the retardation coefficient on the fracture surface $(-), v_{f}$ is the groundwater velocity in the fracture $(\mathrm{L} / \mathrm{T}), \mathrm{z}$ is the special coordinate along the fracture $(\mathrm{L}), \mathrm{Q}_{\mathrm{m}}$ is the mass transfer flux at the fracturematrix interface $\left(\mathrm{M} / \mathrm{T} / \mathrm{L}^{2}\right), \mathrm{b}$ is the half aperture of the fracture $(\mathrm{L})$, and $\lambda$ is the first-order degradation rate $(1 / \mathrm{T})$. 
The transport in the matrix perpendicular to the fracture is described by the onedimensional diffusion equation:

$$
\mathrm{R}_{\mathrm{m}} \frac{\partial \mathrm{C}_{\mathrm{m}}}{\partial \mathrm{t}}-\mathrm{D}_{\mathrm{m}} \frac{\partial^{2} \mathrm{C}_{\mathrm{m}}}{\partial \mathrm{x}^{2}}+\lambda \mathrm{C}_{\mathrm{m}}=0
$$

where $C_{m}$ is the aqueous concentration in the matrix $\left(M / L^{3}\right), R_{m}$ is the retardation factor due to sorption and $D_{m}$ is the effective diffusion coefficient $\left(\mathrm{L}^{2} / \mathrm{T}\right)$. The effective diffusion coefficient is defined as $D_{m}=\tau D_{d}$ (Bear, 1972), with $\tau$ the matrix tortuosity (-) and $D_{d}$ the free diffusion coefficient in water $\left(\mathrm{L}^{2} / \mathrm{T}\right)$. As a first approximation, $\tau$ can be assumed equal to the matrix porosity $\phi$ (Parker et al., 1994).

Linear sorption is assumed in both the matrix and fracture and the retardation coefficients are $\mathrm{R}_{\mathrm{m}, \mathrm{i}}=1+\frac{\rho_{\mathrm{b}}}{\phi} \mathrm{K}_{\mathrm{d}, \mathrm{i}}$ and $\mathrm{R}_{\mathrm{f}}=1+\frac{\mathrm{K}_{\mathrm{f}}}{\mathrm{b}}$, where $\rho_{\mathrm{b}}$ is the bulk density $\left(\mathrm{M} / \mathrm{L}^{3}\right), \phi$ is the porosity of the matrix material, $\mathrm{K}_{\mathrm{d}}=\mathrm{f}_{\mathrm{oc}} \mathrm{K}_{\mathrm{oc}}$ is the distribution coefficient $\left(\mathrm{L}^{3} / \mathrm{M}\right)$ with foc being the fraction of organic carbon, $\mathrm{K}_{\mathrm{oc}}$ the partition coefficient with respect to organic matter, and $\mathrm{K}_{\mathrm{f}}$ the distribution coefficient for the fracture wall (L) (Freeze and Cherry, 1979). In this paper, $R_{f}$ is assumed equal to retardation in the matrix $R_{m}$ (Jørgensen et al., 1998; 2002).

The coupling between the matrix and fracture equations is provided by a requirement of continuity of concentration and flux at the fracture-matrix interface where the mass transfer flux $Q_{m}$ at the matrix-fracture interface is defined by Fick's first law:

$\mathrm{Q}_{\mathrm{m}}=-\left.\phi \mathrm{D}_{\mathrm{m}} \frac{\partial \mathrm{C}_{\mathrm{m}}}{\partial \mathrm{x}}\right|_{\mathrm{x}=\mathrm{b}}$

and $\mathrm{C}_{\mathrm{m}}(\mathrm{b}, \mathrm{z}, \mathrm{t})=\mathrm{C}_{\mathrm{f}}(\mathrm{z}, \mathrm{t})$ at the fracture-matrix interface. The boundary conditions for Eq.(1) and (2) depend on the model considered (see Appendix).

The analytical solutions to Eq.(1) and (2) with different initial and boundary conditions are found using the Laplace transform and details are presented in the Appendix. 


\subsection{Model 1 - Source overlying fractured media}

The analytical solution to conceptual model 1a shown in Fig. 2 is:

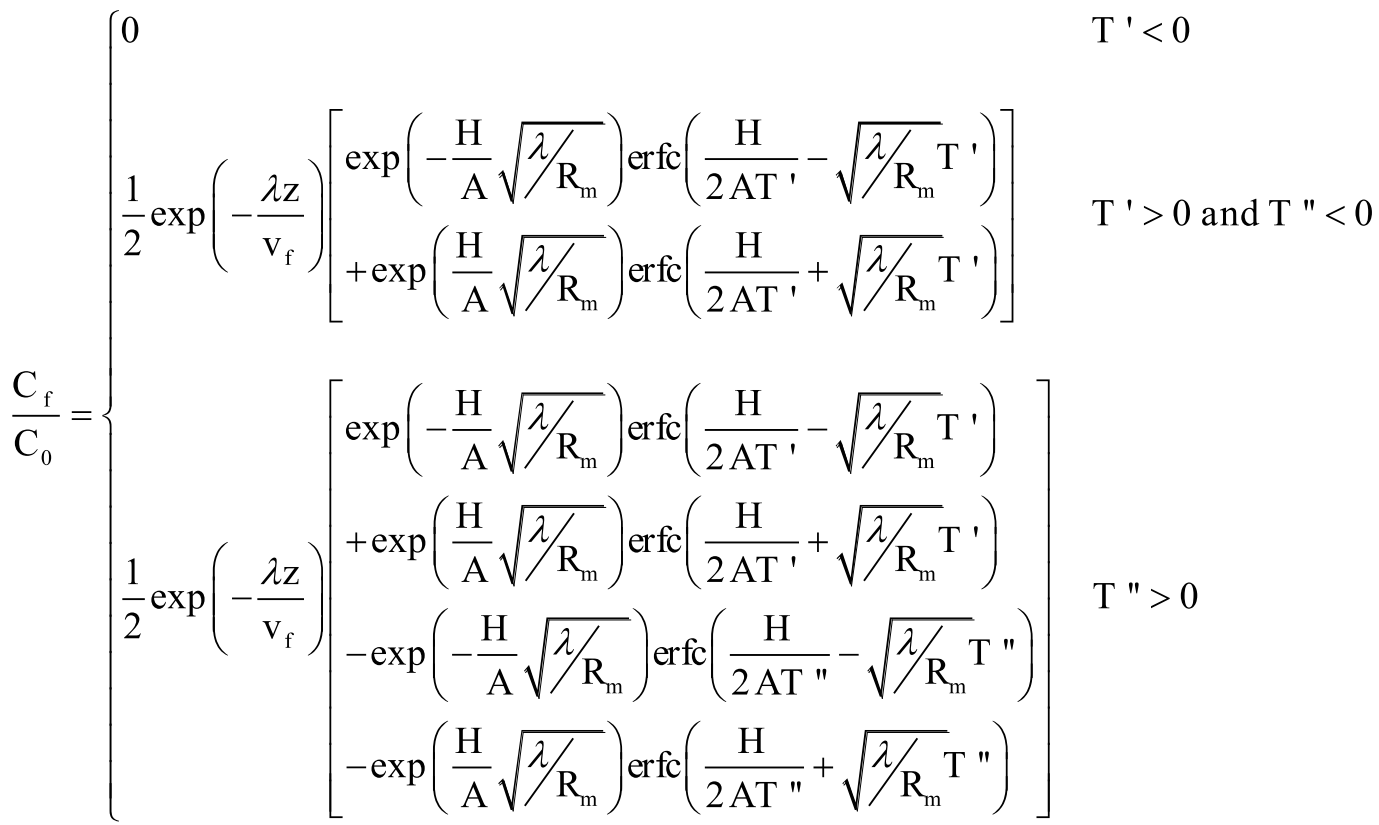

$$
\begin{aligned}
& \mathrm{T}^{\prime}<0
\end{aligned}
$$

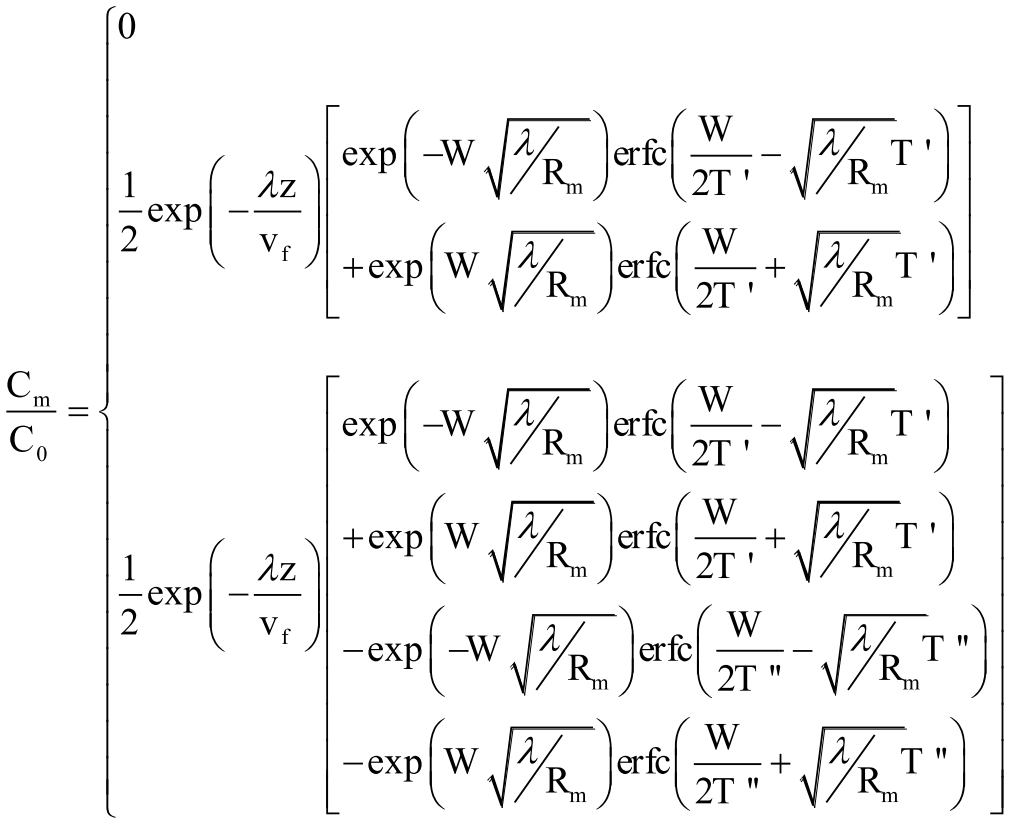

where 


$$
\begin{aligned}
\mathrm{A} & =\frac{\mathrm{b} \mathrm{R}_{\mathrm{f}}}{\phi \sqrt{\mathrm{R}_{\mathrm{m}} \mathrm{D}_{\mathrm{m}}}} \\
\mathrm{H} & =\frac{\mathrm{R}_{\mathrm{f}} \mathrm{z}}{\mathrm{v}_{\mathrm{f}}} \\
\mathrm{W} & =\frac{\mathrm{H}}{\mathrm{A}}+\sqrt{\mathrm{R}_{\mathrm{m}} / \mathrm{D}_{\mathrm{m}}}(\mathrm{x}-\mathrm{b}) \\
\mathrm{T}^{\prime} & =\sqrt{\mathrm{t}-\mathrm{H}} \\
\mathrm{T}^{\prime} & =\sqrt{\mathrm{t}-\mathrm{a}-\mathrm{H}}
\end{aligned}
$$

For model $1 \mathrm{~b}$ in Fig. 2, the solution reduces to the two first terms, for infinite T" (the source is not removed).

Furthermore a steady-state concentration can be calculated for model $1 \mathrm{~b}$ :

$$
\begin{aligned}
& \frac{\mathrm{C}_{\mathrm{f}}}{\mathrm{C}_{0}}=\exp \left(-\frac{\lambda \mathrm{z}}{\mathrm{v}_{\mathrm{f}}}\right) \exp \left(-\frac{\mathrm{H} \sqrt{\lambda / \mathrm{R}_{\mathrm{m}}}}{\mathrm{A}}\right) \\
& \frac{\mathrm{C}_{\mathrm{m}}}{\mathrm{C}_{0}}=\exp \left(-\frac{\lambda \mathrm{z}}{\mathrm{v}_{\mathrm{f}}}\right) \exp \left(-\sqrt{\lambda / \mathrm{R}_{\mathrm{m}} \mathrm{W}}\right)
\end{aligned}
$$

An analytical solution to model $1 \mathrm{~b}$ (constant input concentration) for radioactive decay was presented by Tang et al. (1981). The solution was modified to account for the fact that degradation occurs in the aqueous phase only, which can result in significantly higher leaching concentrations for sorbing compounds.

\subsection{Model 2 - Contaminated fractured media with uniform initial concentration}

This model differs from the previous one, as the matrix is assumed to be initially contaminated and the water entering the system at the top of the fracture is devoid of contaminant.

The solution for this model is given by:

$$
\frac{\mathrm{C}_{\mathrm{f}}}{\mathrm{C}_{\mathrm{I}}}= \begin{cases}\exp \left(-\lambda / \mathrm{R}_{\mathrm{m}} \mathrm{t}\right)-\left(\exp \left(-\lambda \mathrm{z} / \mathrm{v}_{\mathrm{f}}\right) \exp \left(-\lambda / \mathrm{R}_{\mathrm{m}} \mathrm{T}^{\prime 2}\right) \operatorname{erfc}\left(\frac{\mathrm{H}}{2 \mathrm{AT}^{\prime}}\right)\right) & \mathrm{T}^{\prime}>0 \\ \exp \left(-\lambda / \mathrm{R}_{\mathrm{m}}{ }^{\mathrm{t}}\right) & \mathrm{T}^{\prime}<0\end{cases}
$$




$$
\frac{\mathrm{C}_{\mathrm{m}}}{\mathrm{C}_{\mathrm{I}}}= \begin{cases}\exp \left(-\lambda / \mathrm{R}_{\mathrm{m}} \mathrm{t}\right)-\left(\exp \left(-\lambda \mathrm{z} / \mathrm{v}_{\mathrm{f}}\right) \exp \left(-\lambda / \mathrm{R}_{\mathrm{m}} \mathrm{T}^{\prime 2}\right) \operatorname{erfc}\left(\frac{\mathrm{W}}{2 \mathrm{~T}^{\prime}}\right)\right) & \mathrm{T}^{\prime}>0 \\ \exp \left(-\lambda / \mathrm{R}_{\mathrm{m}}{ }^{\mathrm{t}}\right) & \mathrm{T}^{\prime}<0\end{cases}
$$

\subsection{Coupling to groundwater}

The models presented in this study can be used to assess the leaching concentration from a fractured media to an underlying aquifer. The main objective when performing risk assessment is often to calculate the concentration in the aquifer and to compare this value with the maximum allowed contaminant levels (MCLs). Therefore it is necessary to couple the fractured media leaching model to a simple groundwater model. In many risk assessment tools, the contamination of groundwater is calculated from the contaminant mass discharge from the contaminant source to the groundwater (Einarson and Mackay, 2001; Tait et al., 2004a; Troldborg et al., 2008). Under the assumption of complete mixing of the leaching flux at the bottom of the fractured media, the overlying fractured system can be seen as a contaminant source located at the water table for the aquifer. The mass discharge to groundwater can thus be calculated:

$$
\mathrm{J}_{\text {frac }-\mathrm{gw}}=\mathrm{C}_{\mathrm{f}} \mathrm{A}_{\text {tont }} \mathrm{I}
$$

where $\mathrm{C}_{\mathrm{f}}$ is the leaching concentration at the fracture outlet, $\mathrm{A}_{\text {cont }}$ is the contaminated area at the water table and $\mathrm{I}$ is the net infiltration rate. $\mathrm{A}_{\mathrm{cont}}$ can be approximated by the contaminant source area overlying the fractured media for model 1, and by the area over which the fractured media is contaminated for model 2.

The aquifer concentration at a chosen distance from the source can then be calculated using the dilution factor model (DAF) from US EPA (1996), which considers simple mixing with the clean groundwater: 
$\mathrm{C}_{\mathrm{aq}}=\frac{\mathrm{J}_{\text {frac }-\mathrm{gw}}}{\mathrm{A}_{\text {cont }} \mathrm{I}+\mathrm{K}_{\mathrm{aq}} \mathrm{i}_{\mathrm{aq}} \mathrm{d}_{\mathrm{m}} \sqrt{\mathrm{A}_{\text {cont }}}}=\frac{\mathrm{C}_{\mathrm{f}}}{\mathrm{DAF}}$ where $\mathrm{DAF}=1+\frac{\mathrm{K}_{\mathrm{aq}} \mathrm{i}_{\mathrm{aq}} \mathrm{d}_{\mathrm{m}}}{\mathrm{I} \sqrt{\mathrm{A}_{\mathrm{cont}}}}$

where $\mathrm{K}_{\mathrm{aq}}$ is the hydraulic conductivity of the aquifer $(\mathrm{L} / \mathrm{T}), \mathrm{i}_{\mathrm{aq}}$ is the hydraulic gradient in the aquifer and $\mathrm{d}_{\mathrm{m}}$ is the mixing zone depth. This concentration can be compared with measured concentrations in the aquifer, using the screen length as mixing zone depth, to assess how the model compares with field observations.

\subsection{Choice of parameters}

The parameters for a specific contaminant $\left(D_{d}, K_{d}, \lambda\right)$ can be found in databases for risk assessment (e.g., Danish EPA, 2002a; US EPA, 2010a), while the parameters for the physical properties of the fractured media can be found in the literature. Extensive fracture mapping and hydraulic experiments have been performed in fractured clay tills in Denmark and North America (Fredericia, 1990; Jakobsen and Klint, 1999; Jørgensen et al., 2002; 2003; 2004; Klint and Gravesen, 1999; McKay et al., 1993b; 1999; McKay and Fredericia, 1995) and the results of these studies can be used to provide typical fracture spacing, aperture and matrix porosity when site specific parameters are lacking. The measured matrix porosity $(\phi)$ ranged between 0.23 and 0.35 so a typical value of 0.3 will be used in the case studies. The fracture flow velocity $\left(\mathrm{v}_{\mathrm{f}}\right)$ can be calculated from the fracture aperture $(2 \mathrm{~b})$ and the vertical hydraulic gradient (i) using the cubic law (Snow, 1969). Measurements of fracture apertures are limited in the literature, but this parameter can be estimated from the bulk hydraulic conductivity (ranged between $10^{-9}$ and $6 \times 10^{-8}$, with typical value $10^{-8} \mathrm{~m} / \mathrm{s}$ (Fredericia, 1990)) and the fracture spacing (2B) (McKay et al., 1993a), under the assumption of zero flow in the matrix, which is reasonably approximated by typical hydraulic conductivities of $<10^{-9} \mathrm{~m} / \mathrm{s}$ for the matrix of clayey till. The fracture spacing was shown to increase with increasing depth from around 1 meter at 5 mbs to 2-3 meters at 8.5 mbs (Jørgensen et al., 2003; McKay et al., 
1993a) and value of 5 meters is suggested for thicker clayey tills (Jørgensen et al., 2004). For such fracture spacings, the assumption of a single fracture model is reasonable (see Supplementary information).

In the case studies below the typical parameters are used, except when site specific data were available (for ex. matrix porosity in Case I).

\subsection{D-EPM model}

In order to assess the need for a specific tool for risk assessment in fractured media, the developed model is compared to a one-dimensional EPM model defined by:

$$
\mathrm{R}_{\mathrm{m}} \frac{\partial \mathrm{C}}{\partial \mathrm{t}}=\mathrm{D}_{\mathrm{z}} \frac{\partial^{2} \mathrm{C}}{\partial \mathrm{z}^{2}}-\mathrm{v}_{\mathrm{EPM}} \frac{\partial \mathrm{C}}{\partial \mathrm{z}}-\lambda \mathrm{C}
$$

where $\mathrm{v}_{\mathrm{EPM}}$ is the flow velocity in the equivalent porous media (depending on the bulk hydraulic conductivity, the hydraulic gradient and the equivalent porosity) and the longitudinal hydrodynamic dispersion $\mathrm{D}_{\mathrm{z}}$ is defined as:

$$
\mathrm{D}_{\mathrm{z}}=\alpha_{\mathrm{L}} \mathrm{v}_{\mathrm{EPM}}+\mathrm{D}_{\mathrm{m}}
$$

The analytical solutions for Eq.(11) for conceptual models $1 \mathrm{a}, 1 \mathrm{~b}$ and 2 are given by van Genuchten and Alves (1982, p.60).

\section{$5 \quad$ Results}

\subsection{Comparison of the three fracture models}

The three models (1a, 1b and 2) are applied for the case of a conservative $(\lambda=0)$ and a degradable compound $\left(\lambda=0.2 \mathrm{y}^{-1}\right)$ with the parameters shown in Table 1 . 
Table 1

Parameters used in DF tool

\begin{tabular}{ll}
\hline Parameter & Value \\
\hline Fracture aperture $2 \mathrm{~b}(\mu \mathrm{m})$ & 25 \\
Matrix porosity $(-)$ & 0.3 \\
Velocity in fracture $(\mathrm{m} / \mathrm{y})$ & 2000 \\
Diffusion coefficient in matrix $\mathrm{D}_{\mathrm{m}}\left(\mathrm{m}^{2} / \mathrm{y}\right)$ & $10^{-3}$ \\
Retardation factor $\mathrm{R}_{\mathrm{m}}=\mathrm{R}_{\mathrm{f}}$ & 5 \\
Degradation rate $\lambda\left(\mathrm{y}^{-1}\right)$ & $0-0.2$ \\
\hline
\end{tabular}

For model 1a, the source is assumed to have overlain the fractured media for 20 years $(\mathrm{a}=20$ years in Eq.(4)).

Fig. 3. Breakthrough curves for the three models at $\mathrm{z}=5 \mathrm{~m}$ for a conservative $(\lambda=0)$ and a degradable compound $\left(\lambda=0.1 \mathrm{y}^{-1}\right)$. For model 1a, the source is released between $\mathrm{t}=0$ and $\mathrm{t}=20$ years.

In many risk assessment applications, only steady state model output is considered. But Fig. 3 shows that the transient behavior is important, especially for the case of conservative compounds, where the breakthrough curves do not reach steady-state $\left(\mathrm{C}=\mathrm{C}_{0}\right)$ after a hundred years. For the case of biodegradable compounds, it takes 40 years to reach steady-state for model $1 \mathrm{~b}$.

Fig. 3 also shows that microbial degradation is an important attenuation process. Degradation shortens the leaching time to an underlying aquifer from more than 100 years to less than 60 years for models $1 \mathrm{a}$ and 2 for both a conservative and a slowly biodegradable compound. Furthermore it can be seen that the outlet concentration decreases quickly for model 2, due to the mass transfer limitations from matrix to fracture. This phenomenon contributes to the attenuation of contaminants in the fractured media and needs to be taken into account when assessing risk to groundwater. 


\subsection{Comparison with experimental data}

In order to verify the ability of the developed model to simulate fracture flow problems, it was applied to a range of published experimental datasets. The application to column experimental data from Jørgensen et al. (1998) is illustrated in this section. Undisturbed columns of fractured clayey till were used in tracer experiments with chloride and the pesticide MCPP (Jørgensen et al. 1998). Chloride is a conservative tracer, while MCPP can sorb onto the clay matrix. Both tracers were injected in steady-state water flows through three columns containing sediments sampled from different depths in the field. The three columns are characterized by different fracture systems (spacing and aperture). In Jørgensen et al. (1998), the numerical FRACTRAN model was used to simulate the breakthrough curves, and the same parameters are used as input for the DF tool (Table 2). The measured and simulated breakthrough curves for one column are shown in Fig. 4. The model simulates the experimental data in all three columns well, both for conservative and sorbing tracers. The results are comparable to those obtained using FRACTRAN, which also accounted for flow in the matrix and parallel fractures.

The DF tool also successfully simulated the column and field experimental data of Hinsby et al. (1996) (column: chloride and bacteriophages), Tang and Weisbrod (2009) (column: bromide and lithium), Jørgensen et al. (2002) (field: bromide and MCPP) and Mortensen et al. (2004) (field: chloride, DBA and fluorescent dyes) (data not shown).

\footnotetext{
Fig. 4. Simulated and measured breakthrough curves for MCPP and chloride in undisturbed column of fractured clayey till. Data from Jørgensen et al. (1998).
} 
Table 2

Parameters used in the case studies

\begin{tabular}{|c|c|c|c|c|}
\hline Parameters & $\begin{array}{l}\text { Column } \\
\text { (Jørgensen et al., 1998) }\end{array}$ & Case I (BAM $\left.{ }^{\mathbf{a}}\right)$ & Case II $\left(\mathrm{TCE}^{\mathrm{b}}\right)$ & $\begin{array}{l}\text { Case III } \\
\text { (MTBE/benzene) }\end{array}$ \\
\hline Model & $1 \mathrm{a}$ & $1 \mathrm{a}$ & 2 & $1 b$ \\
\hline Source duration a & $\begin{array}{l}4.4 \mathrm{~h}\left(\mathrm{Cl}^{-}\right) \\
1.3 \mathrm{~h}(\mathrm{MCPP})\end{array}$ & $31 \mathrm{yr}$ & - & infinite \\
\hline Source area $\left(\mathrm{m}^{2}\right)$ & - & 3000 & 140 & 225 \\
\hline Clay till thickness (m) & 0.5 & 5 & 5 & 6 \\
\hline Fracture spacing 2B (m) & 0.1 & 1 & 1 & 1.3 \\
\hline Fracture aperture $2 \mathrm{~b}(\mu \mathrm{m})$ & 83 & 25 & 25 & 28 \\
\hline Matrix porosity (-) & 0.31 & 0.25 & 0.3 & 0.3 \\
\hline Velocity in fracture $(\mathrm{m} / \mathrm{y})$ & 66576 & 4000 & 4000 & 2320 \\
\hline $\begin{array}{l}\text { Bulk hydraulic } \\
\text { conductivity }(\mathrm{m} / \mathrm{s})\end{array}$ & $6.9 \times 10^{-6}$ & $1 \times 10^{-8}$ & $1 \times 10^{-8}$ & $1 \times 10^{-8}$ \\
\hline Infiltration $(\mathrm{mm} / \mathrm{y})$ & - & 120 & 100 & 50 \\
\hline Vertical gradient (-) & 1 & 0.4 & 0.3 & 0.15 \\
\hline $\begin{array}{l}\text { Input/Initial concentration } \\
(\mathrm{mg} / \mathrm{L})\end{array}$ & 1 & 4.6 & 40 & $\begin{array}{l}0.33(\mathrm{MTBE}) \\
1.8 \text { (benzene) }\end{array}$ \\
\hline $\begin{array}{l}\text { Diffusion coefficient in } \\
\text { matrix } D_{m}\left(\mathrm{~m}^{2} / \mathrm{y}\right)\end{array}$ & $\begin{array}{l}2 \times 10^{-2}\left(\mathrm{Cl}^{-}\right) \\
3 \times 10^{-3}(\mathrm{MCPP})\end{array}$ & $3.4 \times 10^{-3}$ & $5.8 \times 10^{-3}$ & $\begin{array}{l}5.3 \times 10^{-3}(\mathrm{MTBE}) \\
6.2 \times 10^{-3} \text { (benzene) }\end{array}$ \\
\hline Retardation factor $\mathrm{R}_{\mathrm{m}}=\mathrm{R}_{\mathrm{f}}$ & $\begin{array}{l}1\left(\mathrm{Cl}^{-}\right) \\
6.8(\mathrm{MCPP})\end{array}$ & 8.3 & 4.9 & $\begin{array}{l}1.8(\mathrm{MTBE}) \\
4.8 \text { (benzene) }\end{array}$ \\
\hline Degradation rate $\lambda\left(\mathrm{y}^{-1}\right)$ & 0 & 0 & 0 & $\begin{array}{l}0(\mathrm{MTBE}) \\
0.365\end{array}$ \\
\hline
\end{tabular}

a 2,6-dichlorobenzamide

$\mathrm{b}$ trichloroethene

\subsection{Case studies for risk assessment in fractured media}

The experiments presented in the previous section are of short duration (from several hours to days), and are focused on the validation of the conceptual model of fast contaminant breakthrough through fractures and retardation due to diffusion into the matrix. The long term leaching (over years and decades) due to slow back diffusion from the matrix to the fracture system has not been documented with observed data in the literature, because of the long timeframes. In the context of risk assessment, contamination has often occurred over long time periods and the risk should be assessed many years/decades later. 
To illustrate the use of the models in risk assessment, they are applied to three case studies. The case studies are chosen to illustrate the use of the three conceptual models (Fig. 1) for three commonly found pollutants (pesticides, BTEX and chlorinated solvents). The parameters used in the case studies are summarized in Table 2.

\subsubsection{Case I - Diffusive sources of pesticides in a Danish catchment}

The DF tool is applied to assess the risk posed to groundwater and drinking water wells by the pesticide dichlobenil (DCB), which was used in Denmark between 1966 and 1997 (Holtze et al., 2008). DCB is known to degrade to 2,6-dichlorobenzamide (BAM) under aerobic conditions in the upper part of the soil (mainly above 3 meters), with a half-life constant of about 0.5-3 year (Clausen et al., 2007). Below this depth, DCB degradation decreases very quickly with increasing depth. BAM is viewed as recalcitrant in deeper soils and aquifers (Broholm et al., 2001; Holtze et al., 2008). Monitoring data from the waterworks in the catchment shows that BAM is found in many wells during the period 1995-2009, but the actual breakthrough time is unknown.

In this study, the DF tool is used to assess the risk posed by BAM, resulting from the application of DCB on treated soils. It is assumed that all DCB applied on the soil is degraded to BAM within the upper three meters of the soil. This assumption is justified by the fact that DCB is rarely found below 3 meters (Danish EPA, 2002b). The DF tool is then applied to vertical transport of BAM from 3 to $8 \mathrm{mbs}$ through 5 meter thick fractured clayey till, which is the average thickness in the studied area. The parameters are obtained from a study performed in the catchment by Danish EPA (2002b). The input BAM concentration $\left(\mathrm{C}_{0}\right)$ is estimated to be $4600 \mu \mathrm{g} / \mathrm{L}$, based on an effective DCB application of $5 \mathrm{~kg} / \mathrm{ha} / \mathrm{year}$. The sorption coefficient $\mathrm{K}_{\mathrm{d}}$ for BAM in anaerobic clayey till is estimated to be $0.93 \mathrm{~L} / \mathrm{kg}$ at the site (Clausen et al., 2004). The bulk density $\left(\rho_{\mathrm{b}}\right)$ and the porosity $(\phi)$ of the clay matrix are estimated to be $1.95 \mathrm{~kg} / \mathrm{L}$ and 0.25 , respectively. The retardation coefficient in the matrix is 
calculated to be $R_{m}=8.3$. The free diffusion of BAM in water is $4.32 \times 10^{-10} \mathrm{~m}^{2} \cdot \mathrm{s}^{-1}$ (Jørgensen et al., 2003) and the tortuosity is assumed equal to the porosity. The net infiltration through the fractured till is estimated to be $120 \mathrm{~mm} /$ year. The fracture spacing and aperture are assumed to be $1 \mathrm{~m}$ and $25 \mu \mathrm{m}$, respectively, which are typical values for Danish fractured clayey till (McKay et al., 1999). An EPM model is also applied for comparison, with default parameters for the porosity (equal to the total matrix porosity, 25\%) and the longitudinal dispersivity $\left(\alpha_{\mathrm{L}}=0.1 \mathrm{~m}\right)$.

The outputs from the two approaches are used to calculate the expected concentration in the drinking water wells, neglecting the travel time from the sources to the wells. The mass discharge from the sources is calculated using the source area and the infiltration data, and is divided by the yearly pumping rate at the waterworks $\left(800,000 \mathrm{~m}^{3} /\right.$ year), assuming that all contaminated water reaches the supply wells. The results in Fig. 5a show that the presence of pesticides in the wells is well predicted by the DF tool (thick line). BAM shows a fast breakthrough and is expected to persist in the drinking water wells (EC threshold limit of 0.1 mg. $\mathrm{L}^{-1}$ for single pesticide residues in groundwater) until 2050. In contrast the EPM model using the default parameters (dotted line) cannot simulate the data, predicting a BAM breakthrough starting in 2015. Fig. 5a shows that the EPM model can simulate the presence of BAM in 1995 using lower effective porosity and/or higher dispersivity values (dashed lines). Decreasing the porosity results in an earlier breakthrough and the EPM behaves as a "plugflow" model. An increased dispersivity results in an earlier breakthrough but the shape becomes flatter.

Regular monitoring data are available for four drinking wells between 1995 and 2009, and the trend in BAM concentration can be compared with the results of the two modeling approaches (Fig. 5). The concentration in the four drinking wells decreases or stabilizes between 1995 and 2009, corresponding to the results of the DF tool. In contrast the EPM 
model predicts an increasing trend between 1995 and 2009. A combination of a very low effective porosity (3\%) and high dispersivity $(1 \mathrm{~m})$ is necessary to fit the EPM model to the monitoring data. However, these parameters are effective parameters and do not correspond to physical properties. Therefore they can be obtained by calibration but their use for prediction is limited because they are expected to change from site to site, depending on physical scales and flow characteristics. Furthermore an effective porosity of $3 \%$ mimics the presence of preferential flow pathways in the equivalent porous media. It is possible to calibrate the DF tool so that the concentration levels better match the observations (lower infiltration and/or source area), but the objective is to model the presence and the decreasing concentrations observed in the drinking water wells without parameter calibration.

The time series data from the four drinking wells indicate that the presence of fractures is necessary to explain the decreasing trend observed in the BAM concentrations between 1995 and 2009. Furthermore the DF approach corroborates with the geological and experimental knowledge collected at the site. Despite these encouraging results, earlier breakthrough or late time data would increase confidence in model results. However such data is not available.

Fig. 5. a) Simulated BAM concentration using the DF tool (thick line) and the EPM model with various porosity and dispersivity values, compared with measured BAM concentration in height drinking wells between 1995 and 2009 (symbols). b) Zoom on the period 1995 - 2009 to compare the shape of the models and the data.

\subsubsection{Case II - Chlorinated solvents in fractured clayey till}

At a former factory, trichloroethene (TCE) has been used extensively in the 60-70's and has led to the contamination of the saturated clayey till and (to some extent) the underlying chalk aquifer (Miljøkontrollen, 2004). No physical source has been found at the site and the period of TCE contamination is unknown, but the contaminant hotspot is located over an area 
of $140 \mathrm{~m}^{2}$, overlying the regional chalk aquifer, mainly in 5 meters saturated clayey till (3 to 8 mbs). The main contaminant is TCE and degradation has not been observed at the site (aerobic aquifer). The average concentration in the source zone is estimated to be $30 \mathrm{mg} / \mathrm{kg}$ dry soil and the source zone therefore contains about $40 \mathrm{~kg}$, assuming a bulk density $\rho_{\mathrm{b}}$ of $1.95 \mathrm{~kg} / \mathrm{L}$. Assuming a sorption coefficient $\mathrm{K}_{\mathrm{d}}$ of $0.6 \mathrm{~L} / \mathrm{kg}$ and a porosity $\phi$ of 0.3 , the retardation factor in the matrix is $\mathrm{R}_{\mathrm{m}}=4.9$ and the average aqueous concentration in the source zone $\left(\mathrm{C}_{\mathrm{I}}\right)$ is $40 \mathrm{mg} / \mathrm{L}$. The free diffusion of TCE in water is $7.3 \times 10^{-10} \mathrm{~m}^{2} \cdot \mathrm{s}^{-1}$ (US EPA, 2010a). As for the previous example, typical values are used for the fractures in the clayey till with a vertical spacing of $1 \mathrm{~m}$ and an aperture of $25 \mu \mathrm{m}$. The recharge to the regional aquifer is assumed to be $100 \mathrm{~mm} /$ year.

Model 2 (see Fig. 2) is used to assess the leaching concentration to the regional aquifer $\left(\mathrm{C}_{\mathrm{f}}\right)$ and the expected concentration in the monitoring boreholes in the chalk aquifer. The dilution factor $(\mathrm{DAF}=9)$ is calculated using the chalk aquifer characteristics and a mixing zone depth equal to the screen length of the monitoring wells $(2 \mathrm{~m})$.

Fig. 6. TCE concentration in the water leaching from the source zone (left) and in the regional aquifer (right). Results from the DF (-) and EPM (- - models. The measured concentration range in the chalk aquifer is illustrated with a grey box. The timing of observed concentrations relatively to leaching initiation is not known but is between 5 and 25 years. Data from Miljøkontrollen (2006a; 2006b).

The leaching concentration (Fig. 6, left) decreases quickly from $40 \mathrm{mg} / \mathrm{L}$ to $20 \mathrm{mg} / \mathrm{L}$ over a period of 20 years, and has a long tailing with concentration above $10 \mathrm{mg} / \mathrm{L}$ for more than 150 years. In contrast, an EPM model predicts a constant concentration of $40 \mathrm{mg} / \mathrm{L}$ for a period of 50 years, followed by a fast decrease to less than $1 \mathrm{mg} / \mathrm{L}$ after 100 years. The expected concentration in the regional aquifer is shown in Fig. 6 right, for the two approaches. The concentration is expected to remain above $1 \mathrm{mg} / \mathrm{L}$ for at least 50 years. The 
concentrations at the site were measured in the underlying aquifer in three boreholes: B29 where $2.7 \mathrm{mg} / \mathrm{L}$ was measured (Sept 2006); B30 where $1.9 \mathrm{mg} / \mathrm{L}$ was measured (Sept 2006); and B15 with recordings of $1.5 \mathrm{mg} / \mathrm{L}$ (Dec. 2004), $1.25 \mathrm{mg} / \mathrm{L}$ (Jan 2006) and $1.2 \mathrm{mg} / \mathrm{L}$ (Sept. 2006). These data are shown in Fig. 6 with the grey box, as the initial leaching time is not known, but results are similar to those of the DF tool after 20 to 50 years and the order of magnitude of observed concentrations is well predicted by the model.

In general for conceptual model 2 , the leaching time is overestimated by the single fracture model of this paper because the infinite matrix acts as a longer term source than would be the case for a multiple fracture model (see Supplementary information, Fig. S2). The mass discharge to the aquifer is greater than predicted by EPM model, and because the initial concentration in the matrix is uniform and the matrix is infinite in extent, the mass leaching from the fractured media eventually exceeds the initial mass in the system. This has to be taken into account when assessing the risk and leaching timeframes.

\subsubsection{Case III - Contamination with benzene and MTBE}

The DF tool is used to assess the risk posed by a BTEX source overlying a fractured clay geology on an underlying aquifer (Danish EPA, 2003, p. 19-20). Benzene and MTBE have been measured in the source zone $(0.33$ and $1.8 \mathrm{mg} / \mathrm{L}$, respectively), which overlies a 6 meterthick clayey till. The regional aquifer is located under the clayey till layer. A vertical gradient has been measured throughout the saturated clayey till (15\%), and the modeling tool is used to assess the vertical transport of MTBE and benzene through 6 meters of fractured porous media. According to the redox conditions at the site (anaerobic), MTBE is assumed not to be degraded and a conservative first order degradation rate is used for benzene $\left(\lambda=0.001 \mathrm{~d}^{-1}\right)$. The sorption coefficient $\mathrm{K}_{\mathrm{d}}$ for MTBE and benzene are calculated from $\mathrm{K}_{\mathrm{oc}}$ values $(12$ and 59 1/kg, respectively, (US EPA, 2010b)) and an estimated organic carbon fraction $\mathrm{f}_{\mathrm{oc}}=0.01(-)$. The bulk density $\left(\rho_{\mathrm{b}}\right)$ and the porosity $(\phi)$ of the clay matrix are estimated to be $1.95 \mathrm{~kg} / \mathrm{L}$ and 
0.3 , respectively. The retardation coefficient in the matrix is calculated to be $\mathrm{R}_{\mathrm{m}}=1.8$ and 4.8 , for MTBE and benzene respectively. The free diffusion of MTBE and benzene in water is $5.6 \times 10^{-10}$ and $6.6 \times 10^{-10} \mathrm{~m}^{2} \cdot \mathrm{s}^{-1}$, respectively (US EPA, 2010a).

Model $1 \mathrm{~b}$ (see Fig. 2) is used to assess the leaching concentration to the regional aquifer $\left(\mathrm{C}_{\mathrm{f}}\right)$ and the expected concentration in the monitoring well in the aquifer. The dilution factor $(\mathrm{DAF}=64)$ is calculated using the sand aquifer characteristics and a screen length of $2 \mathrm{~m}$. An EPM model is also applied to assess the leaching concentration.

Fig. 7. a) MTBE concentration in leaching water $\left(\mathrm{C}_{\text {leaching }}\right)$ and in underlying groundwater $\left(\mathrm{C}_{\mathrm{GW}}\right)$ (monitoring well) for the DF tool (black) and EPM model (grey). b) Benzene concentration in leaching water and in underlying groundwater (monitoring well) for the DF tool (black) and EPM model (grey). Note the break in yaxis. The arrows indicate the measured concentration levels in the monitoring well in the aquifer (MTBE, 0.73 mg/L and benzene, $0.19 \mathrm{mg} / \mathrm{L})$. Data from Danish EPA (2003, p. 19-20).

For the conservative compound (MTBE), the DF tool predicts a breakthrough time earlier than the EPM model (2 and 35 years, respectively, for $C_{\text {leaching }}$ above $0.1 \mu \mathrm{g} / \mathrm{L}$ ), due to the fast downward pathways along the fractures. Furthermore, the transient behavior can be compared with the steady-state solution of conceptual model 1b (Eq.(6)) (solid line in Fig. 7a). It takes more than 100 years for the transient solution to reach the steady-state concentration $\left(\mathrm{C}_{\text {leaching }}\right.$ $=\mathrm{C}_{0}=0.33 \mathrm{mg} / \mathrm{L}$ ). The predicted concentrations in the underlying groundwater (around 0.004 $\mathrm{mg} / \mathrm{L}$ for the DF tool) are below the measured concentration $(0.73 \mathrm{mg} / \mathrm{L})$. The Danish groundwater criteria for MTBE (5 $\mu \mathrm{g} / \mathrm{L}$, Danish EPA, 2008) is expected to be exceeded after 90 and 500 years for the EPM and DF models, respectively, if the contaminant source remains. This illustrates the importance of considering the transient behavior of vertical contaminant leaching through low permeability media. 
For the degradable compound (benzene), the steady-state leaching concentration is 130 $\mu \mathrm{g} / \mathrm{L}$ in the DF model and $0 \mu \mathrm{g} / \mathrm{L}$ for the EPM model. This large difference is due to the fact that the residence time in the clay till is very high for an EPM model (35 years), whereas vertical transport along the fractures is very fast ( 1 day). The benzene breakthrough to the aquifer is well predicted with the DF tool, however the modeled concentration is 100 times lower than measured in the monitoring well $(0.002$ vs. $0.2 \mathrm{mg} / \mathrm{L})$. In contrast, benzene is not predicted to reach the aquifer by the EPM model. In this case study, only the DF model predicts that the groundwater concentration will exceed quality criteria for benzene $(1 \mu \mathrm{g} / \mathrm{L}$, Danish EPA, 2008), while the EPM model gives the incorrect result of zero aquifer concentration and no resultant risk.

\section{Fracture model vs. EPM - Implication for risk assessment}

The developed DF model tool was compared for the three case studies with an equivalent porous media (EPM) model, because it is generally used in common risk assessment tools. As discussed in the case studies section, it is not possible to conclusively demonstrate the correct simulation of observed data with DF tool (vs. EPM) because of a lack of long term data. An important consideration in risk assessment in fractured media should be to ensure that any uncertainty is expressed as an over-and not under-estimation of the risk. However the notion of risk can be difficult to define objectively. Furthermore, for transient simulations, the notion of risk depends on the time at which it is considered. In this paper, the DF and EPM models are compared in terms of peak concentration and leaching time.

For a conservative compound (Fig. 5, Fig. 6 and Fig. 7a) the main difference between the two approaches is the breakthrough time, which is underestimated by the EPM model. The peak concentration is the same for the two approaches with conceptual model $1 \mathrm{~b}\left(\mathrm{C}_{\max }=\mathrm{C}_{0}\right)$, while it is similar for conceptual model 1a (cf. Fig. 5). The predicted leaching time is longer for the DF tool, with long tailing due to high storage capacity in the matrix (cf. Fig. 5 and Fig. 
6). However it should be noted that the leaching time is overestimated with the developed tool due to the single fracture assumption.

For a degradable compound (Fig. 7b), the EPM model predicts a very high attenuation and the peak concentration can be several orders of magnitude lower than the results from the DF tool. The use of EPM model for degradable compounds will therefore result in an underestimation of the risk posed to the underlying aquifer and the results from the DF tool are the most conservative in this case.

\section{$7 \quad$ Model limitations and data needs}

The analytical solutions presented in this study are meant to cover the various common scenarios of contamination of fractured media when assessing the risk posed to an underlying aquifer. For use in a regulatory context, when dealing with numerous contaminated sites and data scarcity, several simplifications are necessary in order to obtain simple analytical solutions. The fracture network is simplified to the minimum by assuming a single fracture embedded in a porous matrix. The models are not suitable for highly fractured media, with small average fracture spacing $(2 \mathrm{~B}>1-1.5 \mathrm{~m})$. Furthermore diffusion is assumed to be the dominant process in the porous matrix, so the models are applicable to low-permeability settings only (such as clayey tills).

Another limitation is the representation of microbial degradation. Several compounds (such as chlorinated solvents and pesticides) can undergo sequential degradation, where the intermediate products are also toxic and should be included in a risk assessment, as it can result in an increased risk for the groundwater (Chambon et al., 2010). This is not considered in the presented tool, but analytical solutions exist for radioactive decay chain and constant input source and could be further developed for the three conceptual models presented here (Sun and Buscheck, 2003). Furthermore the models assume uniform degradation in the matrix and fracture, whereas some studies show that degradation occur preferentially in and around 
the high permeability zones formed by the fracture, especially when the transport of bacteria, reactants or nutrient is limited by diffusion (Hønning et al., 2007; Scheutz et al., 2010). In such cases the attenuation due to degradation will be largely overestimated by the risk assessment tool (Chambon et al., 2010). For degradation occurring only in the fracture domain, it has been shown that the attenuation is negligible (Chambon et al., 2010) and the analytical solutions for conservative compounds can then be used.

Finally the choice of parameters is generally based on limited site specific data and even if the data requirements for such analytical solutions are minimal, standard values from the literature are often necessary. However specific parameters for fractured porous-media (such as fracture spacing, aperture, degradation rates) are relatively limited in the literature.

\section{Conclusions}

The DF tool provides a practical framework for assessing the risk of groundwater contamination, while considering complicating factors of transport through low-permeability fractured media. The tool includes different source geometries, which cover the typical scenarios encountered at contaminated sites situated in low-permeability settings. The comparison of the DF tool with observed data is limited by the lack of historical records documenting early breakthrough and long term leaching. The DF tool is based on geological physical parameters, and is shown to provide valuable information on the risk posed by different contamination sources to the groundwater. In contrast, the EPM approach has fundamentally different output and is not consistent with observed fracture transport mechanisms. The DF tool does not require many additional parameters and should therefore be preferred for use in risk assessment for fractured media. 


\section{Acknowledgement}

We wish to acknowledge Liselotte Clausen from Rambøll A/S and the Hvidovre waterworks for providing the BAM data. This work was conducted as part of a project to develop a risk assessment tool contaminated sites in fractured media for Denmark and was supported by the Danish Environment Protection Agency, the Technical University of Denmark, Danish EPA and REMTEC, Innovative REMediation and assessment TEChnologies for contaminated soil and groundwater, Danish Council for Strategic Research, contract 2104-07-0009. 


\section{Reference List}

ANPA, 2002. ROME: ResOnable Maximum Exposure - Operating Manual. National Agency for Protection of the Environment (Agenzia Nazionale Protezione Ambiente).

Bear, J., 1972. Dynamics of Fluids in Porous Media. Elsevier, New York

Broholm, M. M., Rugge, K., Tuxen, N., Hojberg, A. L., Mosbaek, H., and Bjerg, P. L., 2001. Fate of herbicides in a shallow aerobic aquifer: A continuous field injection experiment (Vejen, Denmark). Water Resources Research. 37 (12), 3163-3176.

Chambon, J. C., Broholm, M. M., Binning, P. J., and Bjerg, P. L., 2010. Modeling multicomponent transport and enhanced anaerobic dechlorination processes in a single fracture clay matrix system. Journal of Contaminant Hydrology. 112, 77-90.

Clausen, L., Arildskov, N. P., Larsen, F., Aamand, J., and Albrechtsen, H. J., 2007.

Degradation of the herbicide dichlobenil and its metabolite BAM in soils and subsurface sediments. Journal of Contaminant Hydrology. 89 (3-4), 157-173.

Clausen, L., Larsen, F., and Albrechtsen, H. J., 2004. Sorption of the herbicide dichlobenil and the metabolite 2,6-dichlorobenzamide on soils and aquifer sediments. Environmental Science \& Technology. 38 (17), 4510-4518.

Danish EPA, 2002a. Guidelines on Remediation of Contaminated Sites - Environmental Guidelines 7. Danish Ministry of Environment. http://www2.mst.dk/Udgiv/publications/2002/87-7972-280-6/pdf/87-7972-281-4.pdf.

Danish EPA, 2002b. Pesticider og vandværker. Udredningsprojekt om BAM-forurening. Hovedrapport. HOH Vand og Miljø A/S, GEO, DTU Miljø, København Universitet, Geologisk Institut, and Danmarks Jordbrugsforskning. 732. (in Danish). http://www2.mst.dk/common/Udgivramme/Frame.asp?http://www2.mst.dk/Udgiv/publikatio ner/2002/87-7972-324-1/html/default.htm.

Danish EPA, 2003. Risikovurdering af MTBE-forurening i forhold til grundvandet. Bilagrapport). Teknologiudviklingsprogrammet for jord- og grundvandsforurening. Rambøll A/S. 785. (in Danish). http://www2.mst.dk/common/Udgivramme/Frame.asp?http://www2.mst.dk/Udgiv/publikatio ner/2003/87-7972-541-4/html/indhold.htm.

Danish EPA, 2008. Liste over kvalitetskriterier i relation til forurenet jord og kvalitetskriterier for drikkevand. (in Danish). http://www.mst.dk/NR/rdonlyres/2EED6D00-3C69-486ABED8-34B1FD527A8D/0/Kvalitetskriterierjord og drikkevand.doc.

Einarson, M. D. and Mackay, D. M., 2001. Predicting impacts of groundwater contamination. Environmental Science \& Technology. 35 (3), 66A-73A.

Fischer, G., Winiwarter, W., Ermolieva, T., Cao, G. Y., Qui, H., Klimont, Z., Wiberg, D., and Wagner, F., 2010. Integrated modeling framework for assessment and mitigation of nitrogen pollution from agriculture: Concept and case study for China. Agriculture Ecosystems \& Environment. 136 (1-2), 116-124. 
Fredericia, J., 1990. Saturated Hydraulic Conductivity of Clayey Tills and the Role of Fractures. Nordic Hydrology. 21 (2), 119-132.

Hinsby, K., McKay, L. D., Jørgensen, P., Lenczewski, M., and Gerba, C. P., 1996. Fracture aperture measurements and migration of solutes, viruses, and immiscible creosote in a column of clay-rich till. Ground Water. 34 (6), 1065-1075.

Holtze, M. S., Sorensen, S. R., Sorensen, J., and Aamand, J., 2008. Microbial degradation of the benzonitrile herbicides dichlobenil, bromoxynil and ioxynil in soil and subsurface environments - Insights into degradation pathways, persistent metabolites and involved degrader organisms. Environmental Pollution. 154 (2), 155-168.

Hønning, J., Broholm, M. M., and Bjerg, P. L., 2007. Role of diffusion in chemical oxidation of PCE in a dual permeability system. Environmental Science \& Technology. 41 (24), 84268432.

Jakobsen, P. R. and Klint, K. E., 1999. Fracture Distribution and Occurrence of DNAPL in a Clayey Lodgement Till. Mass Transport in Fractured Aquifers and Aquitards. Nordic Hydrology. 30 (4/5), 285-300.

Jørgensen, P. R., Hoffmann, M., Kistrup, J. P., Bryde, C., Bossi, R., and Villholth, K. G., 2002. Preferential flow and pesticide transport in a clay-rich till: Field, laboratory, and modeling analysis. Water Resources Research. 38 (11).

Jørgensen, P. R., Klint, K. E. S., and Kistrup, J. P., 2003. Monitoring well interception with fractures in clayey till. Ground Water. 41 (6), 772-779.

Jørgensen, P. R., McKay, L. D., and Kistrup, J. P., 2004. Aquifer vulnerability to pesticide migration through till aquitards. Ground Water. 42 (6-7), 841-855.

Jørgensen, P. R., McKay, L. D., and Spliid, N. H., 1998. Evaluation of chloride and pesticide transport in a fractured clayey till using large undisturbed columns and numerical modeling. Water Resources Research. 34 (4), 539-553.

Kamath, R. K., 2006. BIOBALANCE: A mass balance toolkit. For evaluating source depletion, competition effects, long-term sustainability, and plume dynamics. User's Manual. Groundwater Services Inc.

Klint, K. E. S. and Gravesen, P., 1999. Fractures and biopores in Weichselian clayey till aquitards at Flakkebjerg, Denmark. Nordic Hydrology. 30 (4-5), 267-284.

Kohne, J. M., Kohne, S., and Simunek, J., 2009. A review of model applications for structured soils: b) Pesticide transport. Journal of Contaminant Hydrology. 104 (1-4), 36-60.

McKay, L., Fredericia, J., Lenczewski, M., Morthorst, J., and Klint, K. E. S., 1999. Spatial variability of contaminant transport in a fractured till, Avedore Denmark. Nordic Hydrology. 30 (4-5), 333-360.

McKay, L. D., Cherry, J. A., and Gillham, R. W., 1993a. Field Experiments in A Fractured Clay Till .1. Hydraulic Conductivity and Fracture Aperture. Water Resources Research. 29 (4), 1149-1162. 
McKay, L. D. and Fredericia, J., 1995. Distribution, origin, and hydraulic influence of fractures in a clay-rich glacial deposit. Canadian Geotechnical Journal. 32 (6), 957-975.

McKay, L. D., Gillham, R. W., and Cherry, J. A., 1993b. Field Experiments in A Fractured Clay Till .2. Solute and Colloid Transport. Water Resources Research. 29 (12), 3879-3890.

McKay, L. D., Stafford, P. L., and Toran, L. E., 1997. EPM modeling of a field-scale tritium tracer experiment in fractured, weathered shale. Ground Water. 35 (6), 997-1007.

Miljøkontrollen, 2004. Gammel Kongevej 39, Supplerende forureningsundersøgelse.

Hedeselskabet. (in Danish).

Miljøkontrollen, 2006a. Gammel Kongevej 39, Miljøundersøgelse. Hedeselskabet. (in Danish).

Miljøkontrollen, 2006b. Gl. Kongevej 39, Afværgeforanstaltninger, Dokumentationsrapport. Orbicon A/S, Roskilde. (in Danish).

Mortensen, A. P., Jensen, K. H., Nilsson, B., and Juhler, R. K., 2004. Multiple tracing experiments in unsaturated fractured clayey till. Vadose Zone Journal. 3 (2), 634-644.

Pankow, J. F., Johnson, R. L., Hewetson, J. P., and Cherry, J. A., 1986. An Evaluation of Contaminant Migration Patterns at Two Waste Disposal Sites on Fractured Porous Media in Terms of the Equivalent Porous Medium Epm Model. Journal of Contaminant Hydrology. 1, $65-76$.

Parker, B. L., Chapman, S. W., and Guilbeault, M. A., 2008. Plume persistence caused by back diffusion from thin clay layers in a sand aquifer following TCE source-zone hydraulic isolation. Journal of Contaminant Hydrology. 102 (1-2), 86-104.

Parker, B. L., Gillham, R. W., and Cherry, J. A., 1994. Diffusive Disappearance of Immiscible-Phase Organic Liquids in Fractured Geologic Media. Ground Water. 32 (5), 805820 .

Scheutz, C., Broholm, M. M., Durant, N. D., Weeth, E. B., Jørgensen, T. H., Dennis, P., Jacobsen, C. S., Cox, E. E., Chambon, J. C., and Bjerg, P. L., 2010. Field Evaluation of Biological Enhanced Reductive Dechlorination of Chloroethenes in Clayey Till. Environmental Science \& Technology. 44 (13), 5134-5141.

Shih, D. C. F., 2007. Contaminant transport in one-dimensional single fractured media: semianalytical solution for three-member decay chain with pulse and Heaviside input sources. Hydrological Processes. 21 (16), 2135-2143.

Sidle, R. C., Nilsson, B., Hansen, M., and Fredericia, J., 1998. Spatially varying hydraulic and solute transport characteristics of a fractured till determined by field tracer tests, Funen, Denmark. Water Resources Research. 34 (10), 2515-2527.

Slough, K. J., Sudicky, E. A., and Forsyth, P. A., 1999. Numerical simulation of multiphase flow and phase partitioning in discretely fractured geologic media. Journal of Contaminant Hydrology. 40 (2), 107-136. 
Snow, D. T., 1969. Anisotropic Permeability of Fractured Media. Water Resources Research. $5(6), 1273-1289$.

Spence, L. R., 2001. RISC4. User's Manual. Spence Engineering and BP Oil ltd.

Sudicky, E. A. and Frind, E. O., 1982. Contaminant Transport in Fractured Porous-Media Analytical Solutions for A System of Parallel Fractures. Water Resources Research. 18 (6), 1634-1642.

Sudicky, E. A. and McLaren, R. G., 1992. The Laplace Transform Galerkin Technique for Large-Scale Simulation of Mass-Transport in Discretely Fractured Porous Formations. Water Resources Research. 28 (2), 499-514.

Sun, Y. W. and Buscheck, T. A., 2003. Analytical solutions for reactive transport of Nmember radionuclide chains in a single fracture. Journal of Contaminant Hydrology. 62 (3), $695-712$.

Tait, N. G., Davison, R. M., Whittaker, J. J., Leharne, S. A., and Lerner, D. N., 2004a. Borehole Optimisation System (BOS) - A GIS based risk analysis tool for optimising the use of urban groundwater. Environmental Modelling \& Software. 19 (12), 1111-1124.

Tait, N. G., Lerner, D. N., Smith, J. W. N., and Leharne, S. A., 2004b. Prioritisation of abstraction boreholes at risk from chlorinated solvent contamination on the UK PermoTriassic Sandstone aquifer using a GIS. Science of the Total Environment. 319 (1-3), 77-98.

Tang, D. H., Frind, E. O., and Sudicky, E. A., 1981. Contaminant Transport in Fractured Porous-Media - Analytical Solution for A Single Fracture. Water Resources Research. 17 (3), 555-564.

Tang, X. Y. and Weisbrod, N., 2009. Colloid-facilitated transport of lead in natural discrete fractures. Environmental Pollution. 157 (8-9), 2266-2274.

Therrien, R. and Sudicky, E. A., 1996. Three-dimensional analysis of variably-saturated flow and solute transport in discretely-fractured porous media. Journal of Contaminant Hydrology. $23(1-2), 1-44$.

Troldborg, M., Lemming, G., Binning, P. J., Tuxen, N., and Bjerg, P. L., 2008. Risk assessment and prioritisation of contaminated sites on the catchment scale. Journal of Contaminant Hydrology. 101 (1-4), 14-28.

US EPA, 1996. Soil Screening Guidance: User's Guide. 9355.4-23.

US EPA, 2010a. EPA On-line Tools for Site Assessment Calculation - Diffusion coefficient, http://www.epa.gov/athens/learn2model/part-two/onsite/estdiffusion-ext.htm.

US EPA, 2010b. EPA On-line Tools for Site Assessment Calculation - Retardation factor, http://www.epa.gov/athens/learn2model/part-two/onsite/retard.html.

van der Kamp, G., 1992. Evaluating the effects of fractures on solute transport through fractured clayey aquitards. Conference of the International Association of Hydrogeologists Canadian National Chapter. 
van Genuchten, M. T. and Alves, W. J., 1982. Analytical Solutions of the One Dimensional Convective-Dispersive Solute Transport Equation. Technical Bulletin. United States Department of Agriculture.Agricultural. 1661 


\section{Appendix}

\section{Development of analytical solution for model 1a}

For model 1a, the boundary and initial conditions for Eq.(1) and (2) are

$$
\begin{aligned}
& \mathrm{C}_{\mathrm{f}}(\mathrm{z}, 0)=0 \quad \mathrm{C}_{\mathrm{m}}(\mathrm{x}, \mathrm{z}, 0)=\mathrm{C}_{\mathrm{I}} \\
& \mathrm{C}_{\mathrm{f}}(0, \mathrm{t})=\left\{\begin{array}{ll}
\mathrm{C}_{0} & \mathrm{t}<\mathrm{a} \\
0 & \mathrm{t}>\mathrm{a}
\end{array} \quad \mathrm{C}_{\mathrm{m}}(\mathrm{b}, \mathrm{z}, \mathrm{t})=\mathrm{C}_{\mathrm{f}}(\mathrm{z}, \mathrm{t})\right. \\
& \mathrm{C}_{\mathrm{f}}(\infty, \mathrm{t})=0 \quad \mathrm{C}_{\mathrm{m}}(\infty, \mathrm{z}, \mathrm{t})=0
\end{aligned}
$$

Where $\mathrm{C}_{0}$ is the constant concentration of the source released during $\mathrm{t}=0$ and $\mathrm{t}=\mathrm{a}$ at $\mathrm{z}=0$.

Applying the Laplace transform to Eq.(2) for the matrix gives:

$$
\mathrm{p} \overline{\mathrm{C}_{\mathrm{m}}}-\frac{\mathrm{D}_{\mathrm{m}}}{\mathrm{R}_{\mathrm{m}}} \frac{\partial^{2} \overline{\mathrm{C}_{\mathrm{m}}}}{\partial \mathrm{z}^{2}}+\frac{\lambda}{\mathrm{R}_{\mathrm{m}}} \overline{\mathrm{C}_{\mathrm{m}}}=0
$$

The solution to this second-order differential equation is (using the boundary condition given by Eq.(A.1)):

$$
\overline{\mathrm{C}_{\mathrm{m}}}=\overline{\mathrm{C}_{\mathrm{f}}} \exp \left(-\mathrm{G} \sqrt{\lambda / \mathrm{R}_{\mathrm{m}}}(\mathrm{x}-\mathrm{b})\right)
$$

The gradient of $\overline{\mathrm{C}_{\mathrm{m}}}$ at the interface $\mathrm{x}=\mathrm{b}$ is then

$$
\left.\frac{\partial \overline{\mathrm{C}_{\mathrm{m}}}}{\partial \mathrm{x}}\right|_{\mathrm{x}=\mathrm{b}}=-\overline{\mathrm{C}_{\mathrm{f}}} \mathrm{G} \sqrt{\mathrm{p}+\lambda / \mathrm{R}_{\mathrm{m}}}
$$

Applying Laplace transform to Eq.(1) for a fracture, and after substituting Eq.(A.4) for the interface gradient gives:

$$
\frac{\partial \mathrm{C}_{\mathrm{f}}}{\partial \mathrm{z}}-\frac{\mathrm{R}_{\mathrm{f}}}{\mathrm{v}_{\mathrm{f}}}\left(\mathrm{p}+\lambda / \mathrm{R}_{\mathrm{f}}+\frac{\sqrt{\mathrm{p}+\lambda / \mathrm{R}_{\mathrm{m}}}}{\mathrm{A}}\right) \overline{\mathrm{C}_{\mathrm{f}}}=0
$$

The solution to Eq.(A.5) is of the form:

$$
\overline{\mathrm{C}_{\mathrm{f}}}=\mathrm{C}_{3} \exp \left(-\frac{\lambda \mathrm{z}}{\mathrm{v}_{\mathrm{f}}}\right) \exp (-\mathrm{pH}) \exp \left(-\frac{\mathrm{H} \sqrt{\mathrm{p}+\lambda / \mathrm{R}_{\mathrm{m}}}}{\mathrm{A}}\right)
$$


$\mathrm{C}_{3}$ can be determined by using the Laplace transform of boundary condition defined in Eq.(A.1):

$$
\overline{\mathrm{C}_{\mathrm{f}}}(0, \mathrm{p})=\mathrm{C}_{3}=\mathrm{C}_{0} \frac{1-\exp (-\mathrm{ap})}{\mathrm{p}}
$$

The concentration in the fracture $\mathrm{C}_{\mathrm{f}}$ can be expressed in term of the inverse transform $\mathrm{L}^{-1}$ as:

$$
\frac{\mathrm{C}_{\mathrm{f}}}{\mathrm{C}_{0}}=\exp \left(-\frac{\lambda \mathrm{z}}{\mathrm{v}_{\mathrm{f}}}\right)\left[\begin{array}{l}
\mathrm{L}^{-1}\left\{\frac{1}{\mathrm{p}} \exp (-\mathrm{pH}) \exp \left(-\frac{\mathrm{H} \sqrt{\mathrm{p}+\lambda / \mathrm{R}_{\mathrm{m}}}}{\mathrm{A}}\right)\right\} \\
-\mathrm{L}^{-1}\left\{\frac{1}{\mathrm{p}} \exp (-\mathrm{p}(\mathrm{H}+\mathrm{a})) \exp \left(-\frac{\mathrm{H} \sqrt{\mathrm{p}+\lambda / \mathrm{R}_{\mathrm{m}}}}{\mathrm{A}}\right)\right\}
\end{array}\right\}
$$

To evaluate the inverse transform we use the following identity from Tang et al. (1981):

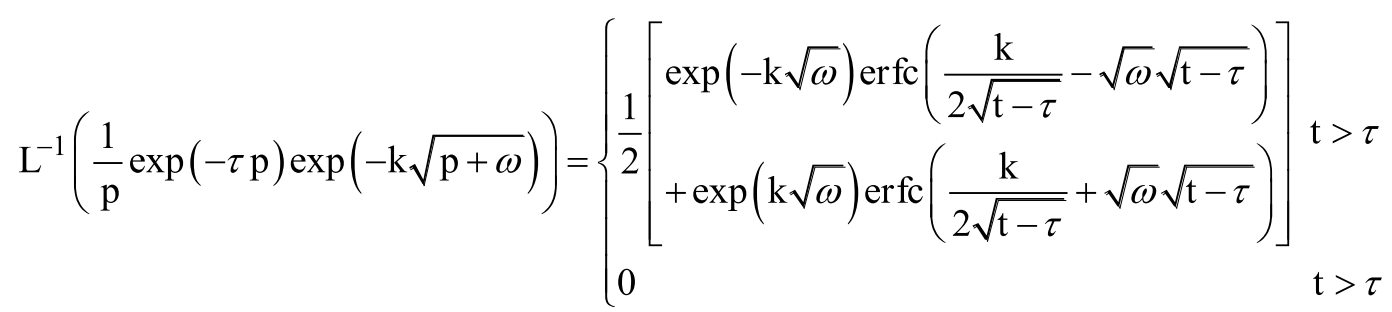

Which gives the solution for the concentration in the fracture Eq.(4) and in the matrix Eq.(5) shown in the main text.

\section{Development of analytical solution for model 2}

For model 2, the boundary and initial conditions for Eq.(1) and (2) are:

$$
\begin{array}{ll}
\mathrm{C}_{\mathrm{f}}(\mathrm{z}, 0)=\mathrm{C}_{\mathrm{I}} & \mathrm{C}_{\mathrm{m}}(\mathrm{x}, \mathrm{z}, 0)=\mathrm{C}_{\mathrm{I}} \\
\mathrm{C}_{\mathrm{f}}(0, \mathrm{t})=0 & \mathrm{C}_{\mathrm{m}}(\mathrm{b}, \mathrm{z}, \mathrm{t})=\mathrm{C}_{\mathrm{f}}(\mathrm{z}, \mathrm{t}) \\
\mathrm{C}_{\mathrm{f}}(\infty, \mathrm{t})=\mathrm{C}_{\mathrm{I}} \exp \left(-\lambda / \mathrm{R}_{\mathrm{f}} \mathrm{t}\right) & \mathrm{C}_{\mathrm{m}}(\infty, \mathrm{z}, \mathrm{t})=\mathrm{C}_{\mathrm{I}} \exp \left(-\lambda / \mathrm{R}_{\mathrm{m}} \mathrm{t}\right)
\end{array}
$$

Where $C_{I}$ is the uniform concentration in the fractured media.

The Laplace transform is defined by:

$$
f^{\prime}(t)=p F(p)-f(t=0)
$$


So the Laplace transform of Eq.(2) is:

$$
\mathrm{pC}_{\mathrm{m}}-\mathrm{C}_{\mathrm{I}}-\frac{\mathrm{D}_{\mathrm{m}}}{\mathrm{R}_{\mathrm{m}}} \frac{\partial^{2} \overline{\mathrm{C}_{\mathrm{m}}}}{\partial \mathrm{z}^{2}}+\frac{\lambda}{\mathrm{R}_{\mathrm{m}}} \overline{\mathrm{C}_{\mathrm{m}}}=0
$$

The solution to this second-order differential equation is of the form:

$$
\begin{aligned}
& \overline{\mathrm{C}_{\mathrm{m}}}=\mathrm{C}_{1} \exp \left(-\mathrm{G} \sqrt{\mathrm{p}+\lambda / \mathrm{R}_{\mathrm{m}}}(\mathrm{x}-\mathrm{b})\right)+\frac{\mathrm{C}_{\mathrm{I}}}{\mathrm{p}+\lambda / \mathrm{R}_{\mathrm{m}}} \\
& \mathrm{G}=\sqrt{\mathrm{R}_{\mathrm{m} / \mathrm{D}_{\mathrm{m}}}}
\end{aligned}
$$

$\mathrm{C}_{1}$ can be determined by using the Laplace transform of the boundary condition in Eq.(A.10):

$$
\begin{aligned}
& \overline{\mathrm{C}_{\mathrm{m}}}(\mathrm{b}, \mathrm{z}, \mathrm{p})=\overline{\mathrm{C}_{\mathrm{f}}}=\mathrm{C}_{1}+\frac{\mathrm{C}_{\mathrm{I}}}{\mathrm{p}+\lambda / \mathrm{R}_{\mathrm{m}}} \\
& \mathrm{C}_{1}=\overline{\mathrm{C}_{\mathrm{f}}}-\frac{\mathrm{C}_{\mathrm{I}}}{\mathrm{p}+\lambda / \mathrm{R}_{\mathrm{m}}}
\end{aligned}
$$

Eq.(A.13) then becomes:

$$
\overline{\mathrm{C}_{\mathrm{m}}}=\overline{\mathrm{C}_{\mathrm{f}}} \exp \left(-\mathrm{G} \sqrt{\mathrm{p}+\lambda / \mathrm{R}_{\mathrm{m}}}(\mathrm{x}-\mathrm{b})\right)+\frac{\mathrm{C}_{\mathrm{I}}}{\mathrm{p}+\lambda / \mathrm{R}_{\mathrm{m}}}\left(1-\exp \left(-\mathrm{G} \sqrt{\mathrm{p}+\lambda / \mathrm{R}_{\mathrm{m}}}(\mathrm{x}-\mathrm{b})\right)\right)
$$

The gradient of $\overline{\mathrm{C}_{\mathrm{m}}}$ at the interface $\mathrm{x}=\mathrm{b}$ is then

$$
\left.\frac{\partial \overline{\mathrm{C}_{\mathrm{m}}}}{\partial \mathrm{x}}\right|_{\mathrm{x}=\mathrm{b}}=-\overline{\mathrm{C}_{\mathrm{f}}} \mathrm{G} \sqrt{\mathrm{p}+\lambda / \mathrm{R}_{\mathrm{m}}}+\frac{\mathrm{C}_{\mathrm{I}}}{\sqrt{\mathrm{p}+\lambda / \mathrm{R}_{\mathrm{m}}}} \mathrm{G}
$$

Applying Laplace transform to Eq.(1) for a fracture, and after substituting Eq.(A.16) for the interface gradient gives:

$$
\frac{\partial \overline{\mathrm{C}_{\mathrm{f}}}}{\partial \mathrm{z}}+\frac{\mathrm{R}_{\mathrm{f}}}{\mathrm{v}_{\mathrm{f}}}\left(\mathrm{p}+\lambda / \mathrm{R}_{\mathrm{f}}+\frac{\sqrt{\mathrm{p}+\lambda / \mathrm{R}_{\mathrm{m}}}}{\mathrm{A}}\right) \overline{\mathrm{C}_{\mathrm{f}}}=\mathrm{C}_{\mathrm{I}} \frac{\mathrm{R}_{\mathrm{f}}}{\mathrm{v}_{\mathrm{f}}}\left(1+\frac{1}{\mathrm{~A} \sqrt{\lambda / \mathrm{R}_{\mathrm{m}}}}\right)
$$

The solution to Eq.(A.17) is of the form: 


$$
\overline{\mathrm{C}_{\mathrm{f}}}=\mathrm{C}_{2}\left(\begin{array}{l}
\exp \left(-\frac{\lambda \mathrm{z}}{\mathrm{v}_{\mathrm{f}}}\right) \exp (-\mathrm{pH}) \\
\exp \left(-\frac{\mathrm{H}}{\mathrm{A}} \sqrt{\mathrm{p}+\lambda / \mathrm{R}_{\mathrm{m}}}\right)
\end{array}\right)+\mathrm{C}_{\mathrm{I}} \frac{\mathrm{A} \sqrt{\mathrm{p}+\lambda / \mathrm{R}_{\mathrm{m}}}}{\sqrt{\mathrm{p}+\lambda / \mathrm{R}_{\mathrm{m}}}} \frac{1}{\mathrm{~A}\left(\mathrm{p}+\lambda / \mathrm{R}_{\mathrm{f}}\right)+\sqrt{\mathrm{p}+\lambda / \mathrm{R}_{\mathrm{m}}}}
$$

The following simplification has to be made in the second term of Eq.(A.18):

$$
\lambda / \mathrm{R}_{\mathrm{f}} \approx \lambda / \mathrm{R}_{\mathrm{m}}
$$

This simplification may over- or underestimate the effective degradation rate in the fracture but the errors introduced by this approximations are very small for most cases.

Substituting Eq.(A.19) into Eq.(A.18) gives:

$$
\overline{\mathrm{C}_{\mathrm{f}}}=\mathrm{C}_{2}\left(\exp \left(-\frac{\lambda \mathrm{z}}{\mathrm{v}_{\mathrm{f}}}\right) \exp (-\mathrm{pH}) \exp \left(-\frac{\mathrm{H}}{\mathrm{A}} \sqrt{\mathrm{p}+\lambda / \mathrm{R}_{\mathrm{m}}}\right)\right)+\frac{\mathrm{C}_{\mathrm{I}}}{\left(\mathrm{p}+\lambda / \mathrm{R}_{\mathrm{m}}\right)}
$$

$\mathrm{C}_{2}$ can be determined by using the Laplace transform of boundary condition defined in Eq.(A.10) and Eq.(A.20) becomes:

$$
\overline{\mathrm{C}_{\mathrm{f}}}=\frac{\mathrm{C}_{\mathrm{I}}}{\left(\mathrm{p}+\lambda / \mathrm{R}_{\mathrm{m}}\right)}\left(1-\left(\exp \left(-\frac{\lambda \mathrm{z}}{\mathrm{v}_{\mathrm{f}}}\right) \exp (-\mathrm{pH}) \exp \left(-\frac{\mathrm{H}}{\mathrm{A}} \sqrt{\mathrm{p}+\lambda / \mathrm{R}_{\mathrm{m}}}\right)\right)\right)
$$

The concentration in the fracture $\mathrm{C}_{\mathrm{f}}$ can be expressed in term of the inverse transform $\mathrm{L}^{-1}$ as:

$$
\mathrm{C}_{\mathrm{f}}=\mathrm{C}_{\mathrm{I}} \exp \left(-\lambda / \mathrm{R}_{\mathrm{m}} \mathrm{t}\right)-\exp \left(-\lambda \mathrm{z} / \mathrm{v}_{\mathrm{f}}\right) \cdot \mathrm{L}^{-1}\left(\frac{\mathrm{C}_{\mathrm{I}}}{\left(\mathrm{p}+\lambda / \mathrm{R}_{\mathrm{m}}\right)} \exp (-\mathrm{pH}) \exp \left(-\frac{\mathrm{H}}{\mathrm{A}} \sqrt{\mathrm{p}+\lambda / \mathrm{R}_{\mathrm{m}}}\right)\right)
$$

(A.22)

To evaluate the inverse transform we use the following identities:

$$
\begin{array}{ll}
\mathrm{L}^{-1}\left(\frac{\exp \left(-k p^{1 / 2}\right)}{\mathrm{p}}\right)=\operatorname{erfc}\left(\frac{\mathrm{k}}{2 \mathrm{t}^{1 / 2}}\right) & \\
\mathrm{L}^{-1}(\mathrm{~F}(\mathrm{p}+\omega))=\exp (-\omega \mathrm{t}) \mathrm{L}^{-1}(\mathrm{~F}(\mathrm{p})) \\
\mathrm{L}^{-1}(\exp (-\tau \mathrm{p}) \mathrm{F}(\mathrm{p}))=\mathrm{f}(\mathrm{t}-\tau) & \mathrm{t}>\tau \\
=0 & \mathrm{t}<\tau
\end{array}
$$


A fourth identity can be obtained by combining the three in Eq.(A.23):

$\mathrm{L}^{-1}\left(\exp (-\tau \mathrm{p}) \frac{\exp \left(-\mathrm{k}(\mathrm{p}+\omega)^{1 / 2}\right)}{\mathrm{p}+\omega}\right)=\exp (-\omega(\mathrm{t}-\tau)) \operatorname{erfc}\left(\frac{\mathrm{k}}{2(\mathrm{t}-\tau)^{1 / 2}}\right)$

Using Eq.(A.24) we can express the inverse transform in Eq.(A.22) as:

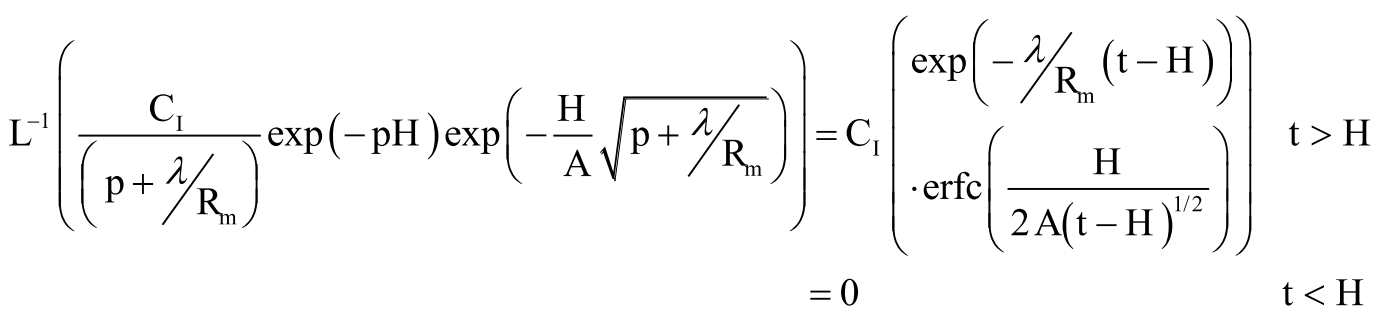

Substituting Eq.(A.25) into Eq.(A.22), we obtain

$$
\begin{aligned}
& \frac{\mathrm{C}_{\mathrm{f}}}{\mathrm{C}_{\mathrm{I}}}=\exp \left(-\lambda / \mathrm{R}_{\mathrm{m}} \mathrm{t}\right)-\left(\exp \left(-\lambda \mathrm{z} / \mathrm{v}_{\mathrm{f}}\right) \exp \left(-\lambda / \mathrm{R}_{\mathrm{m}} \mathrm{T}^{\prime 2}\right) \operatorname{erfc}\left(\frac{\mathrm{H}}{2 \mathrm{AT} \mathrm{T}^{\prime}}\right)\right) \mathrm{T}^{\prime}>0 \\
& \frac{\mathrm{C}_{\mathrm{f}}}{\mathrm{C}_{\mathrm{I}}}=\exp \left(-\lambda / \mathrm{R}_{\mathrm{m}}{ }^{\mathrm{t}}\right) \quad \mathrm{T}^{\prime}<0
\end{aligned}
$$

To find the solution for the porous matrix Eq.(A.21), and Eq.(A.15) are combined to obtain

$$
\begin{aligned}
& \overline{\mathrm{C}_{\mathrm{m}}}=\frac{\mathrm{C}_{\mathrm{I}}}{\left(\mathrm{p}+\lambda / \mathrm{R}_{\mathrm{m}}\right)}\left(1-\exp \left(-\lambda \mathrm{z} / \mathrm{v}_{\mathrm{f}}\right) \exp (-\mathrm{pH}) \exp \left(-\mathrm{W} \sqrt{\mathrm{p}+\lambda / \mathrm{R}_{\mathrm{m}}}\right)\right) \\
& \mathrm{W}=\frac{\mathrm{H}}{\mathrm{A}}+\sqrt{\mathrm{R}_{\mathrm{m}} / \mathrm{D}_{\mathrm{m}}}(\mathrm{x}-\mathrm{b})
\end{aligned}
$$

By using Eq.(A.25), the inverse of Eq.(A.27) is obtained:

$$
\begin{aligned}
& \frac{\mathrm{C}_{\mathrm{m}}}{\mathrm{C}_{\mathrm{I}}}=\exp \left(-\lambda / \mathrm{R}_{\mathrm{m}} \mathrm{t}\right)-\left(\exp \left(-\lambda \mathrm{z} / \mathrm{v}_{\mathrm{f}}\right) \exp \left(-\lambda / \mathrm{R}_{\mathrm{m}} \mathrm{T}^{\prime 2}\right) \operatorname{erfc}\left(\frac{\mathrm{W}}{2 \mathrm{~T}^{\prime}}\right)\right) \mathrm{T}^{\prime}>0 \\
& \frac{\mathrm{C}_{\mathrm{m}}}{\mathrm{C}_{\mathrm{I}}}=\exp \left(-\lambda / \mathrm{R}_{\mathrm{m}} \mathrm{t}\right) \mathrm{T}^{\prime}<0
\end{aligned}
$$



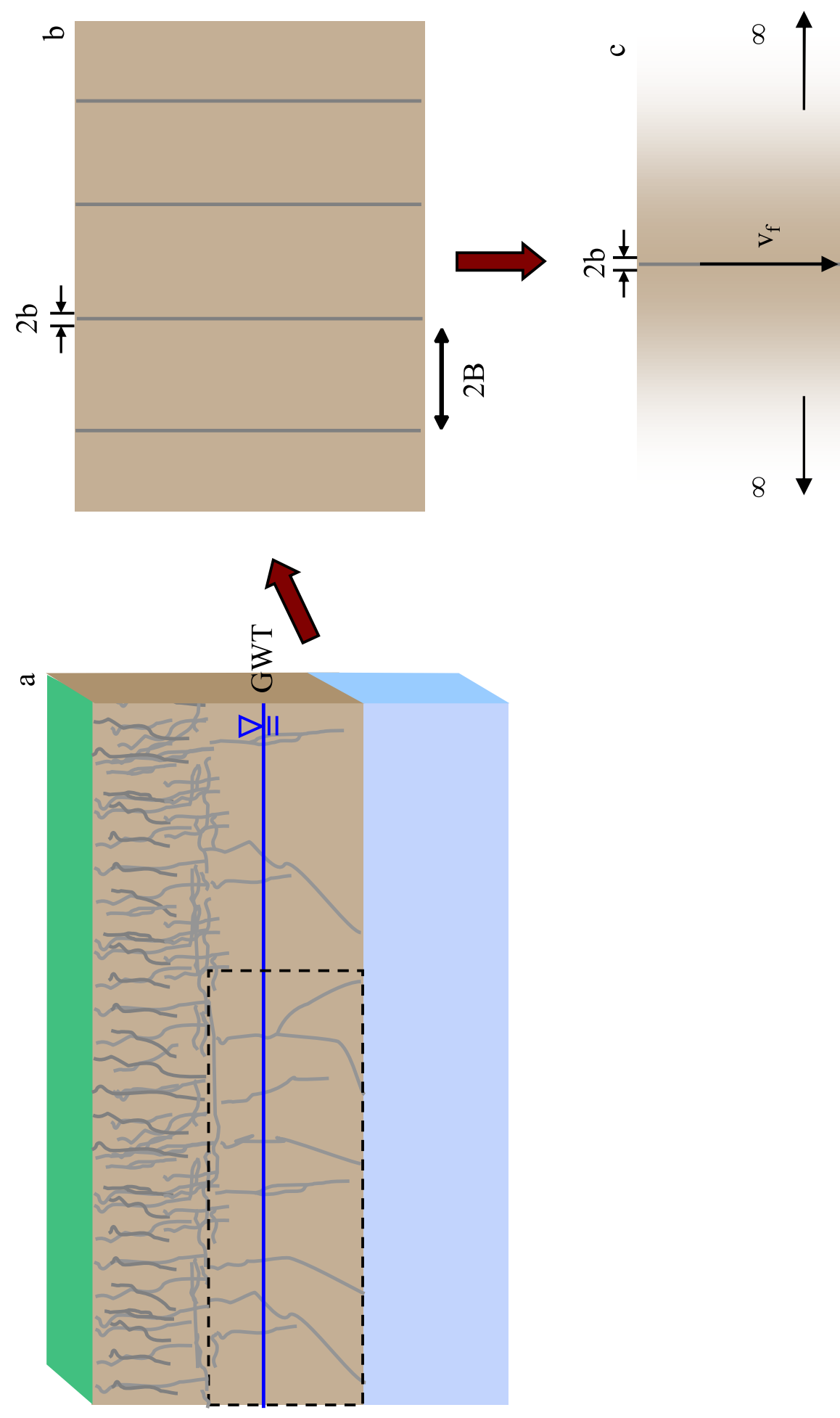

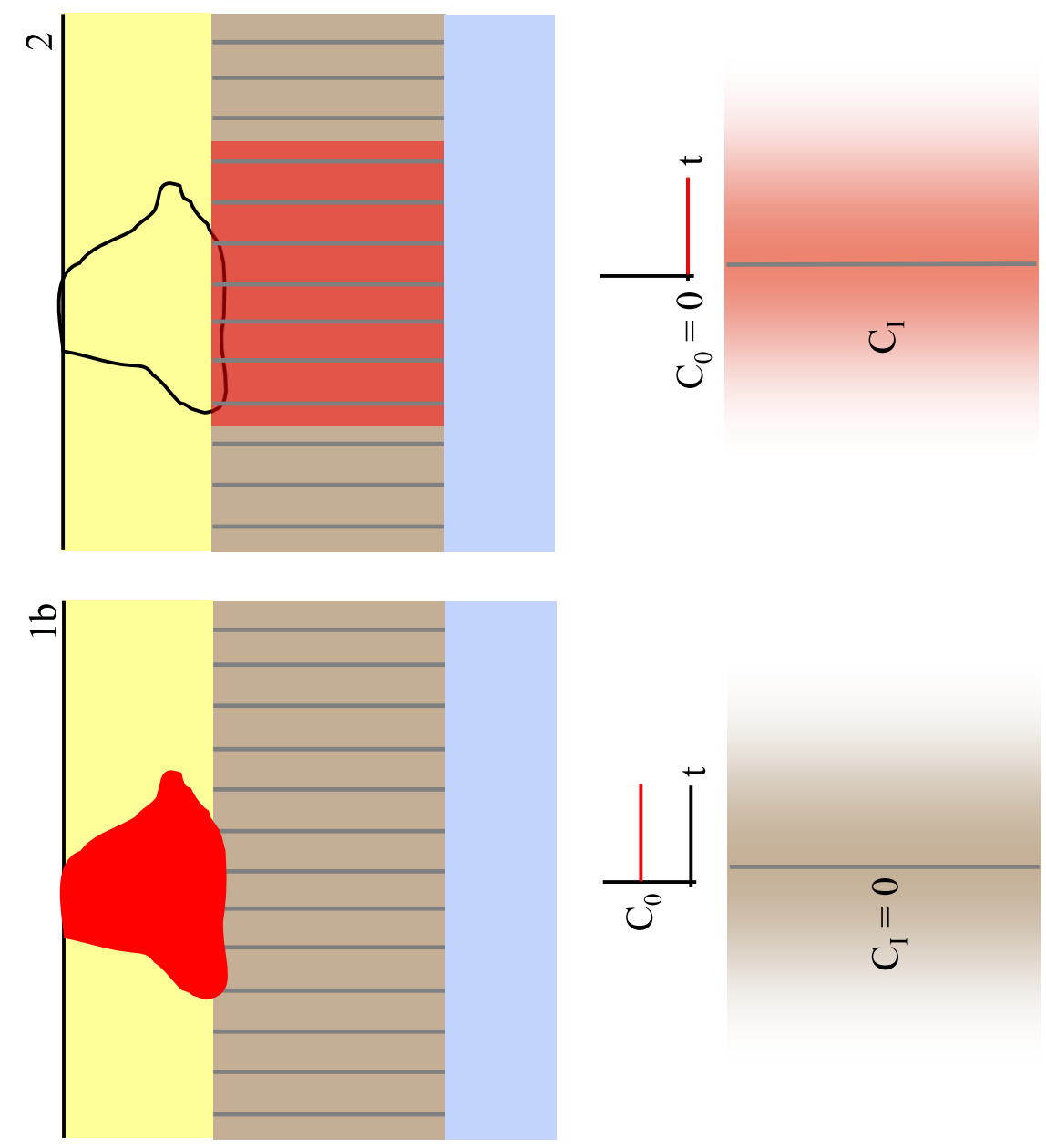

0
11
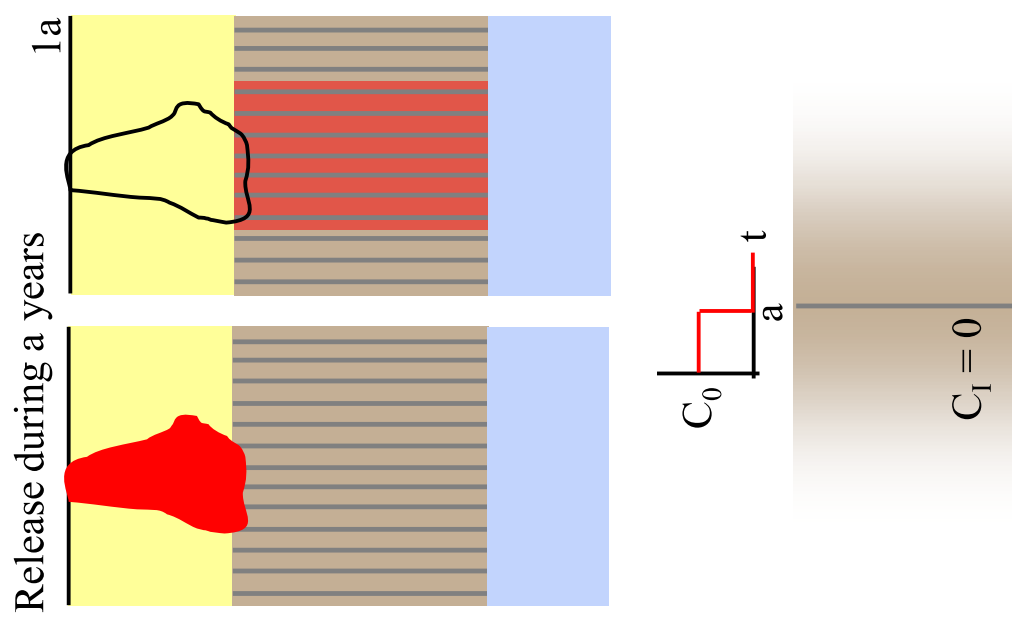
Figure5

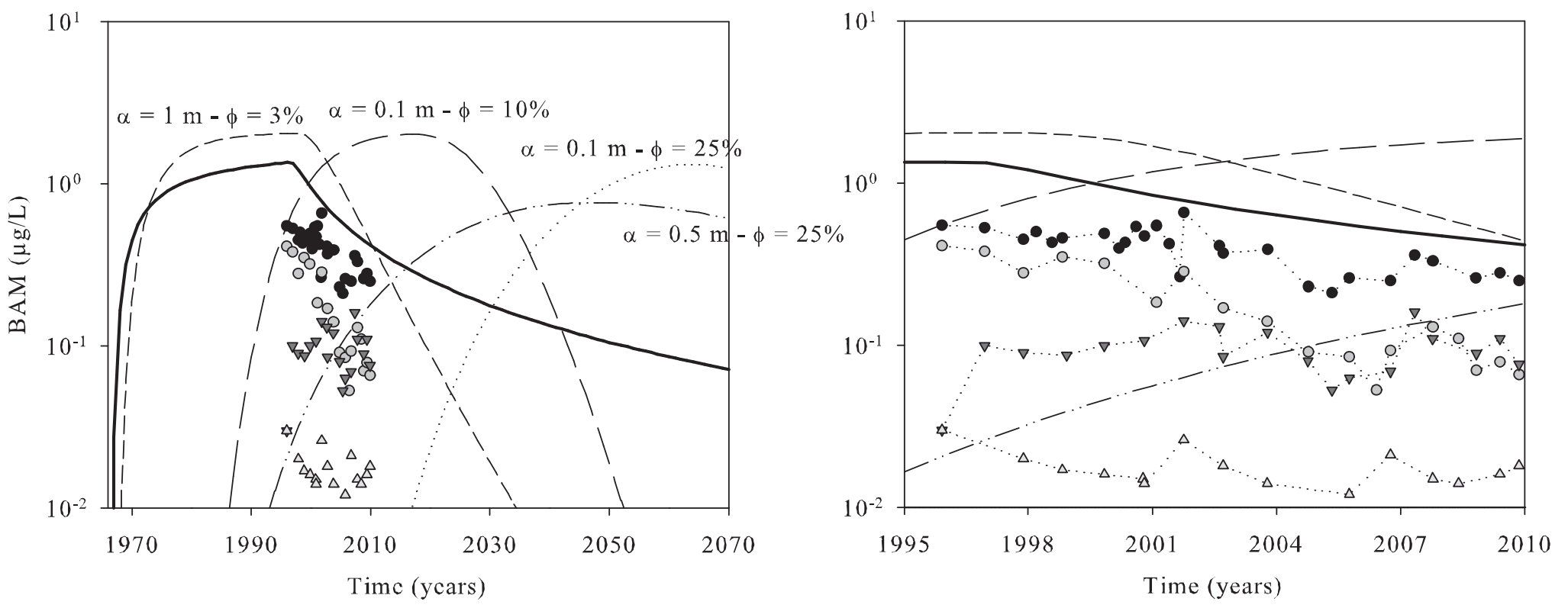




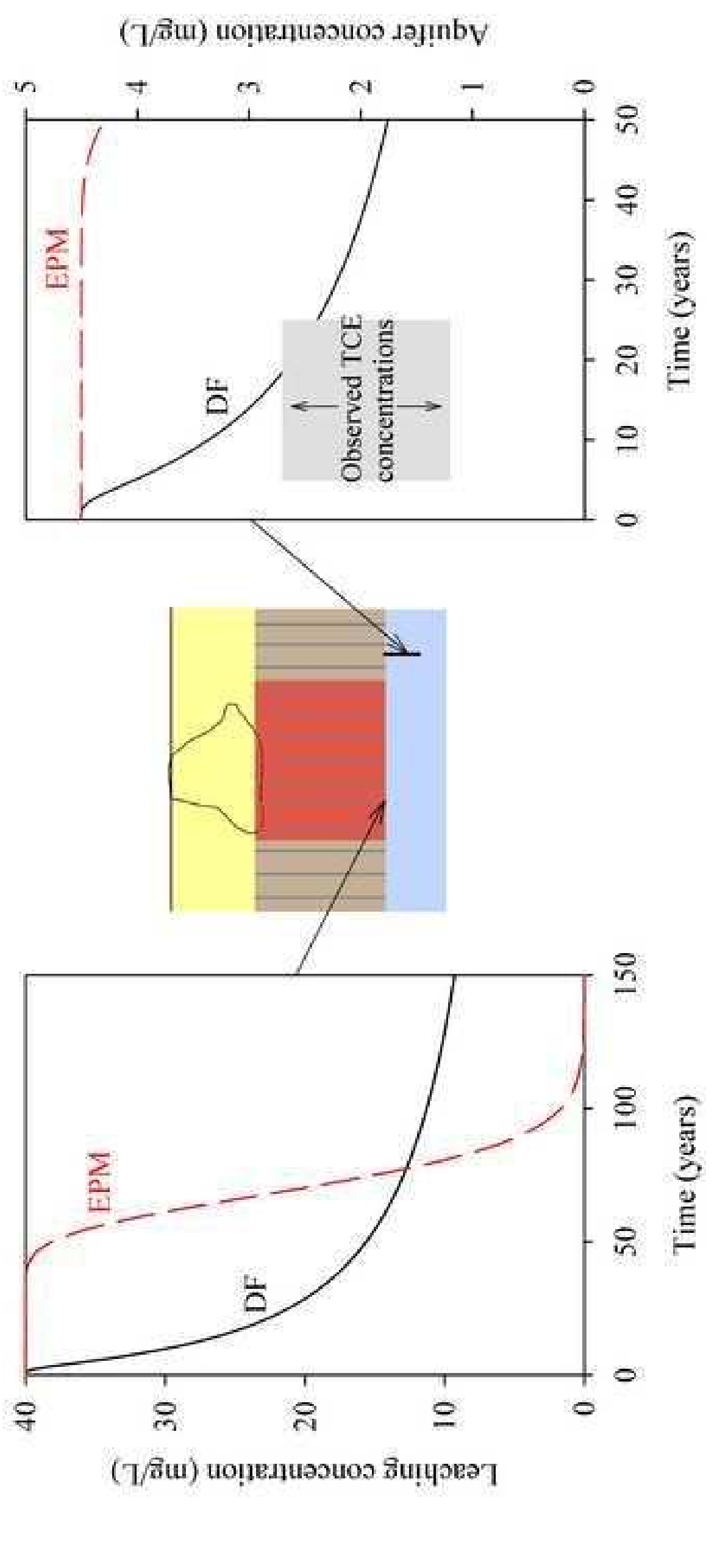



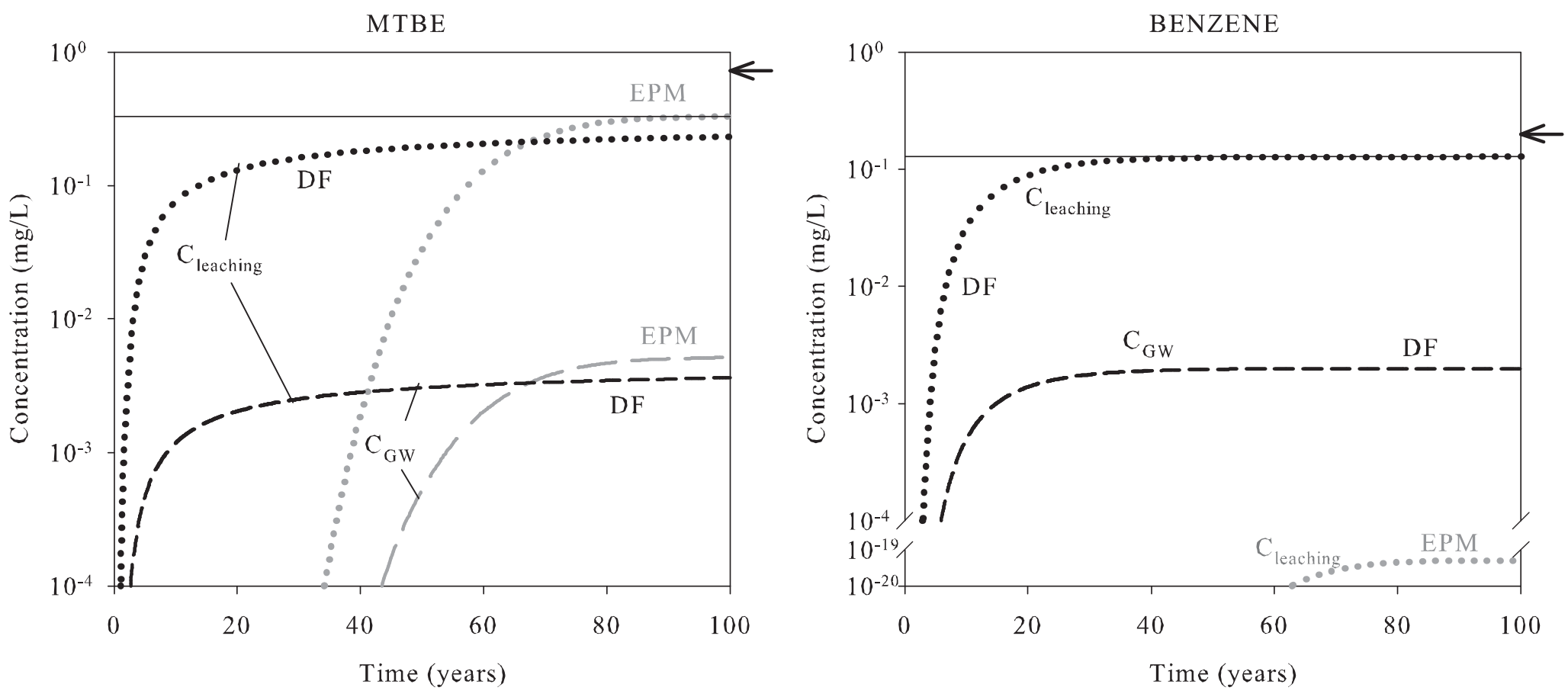


\section{SUPPLEMENTARY INFORMATION}

\section{Single fracture simplification}

3 In this section the use of the single fracture model to simplify a parallel fractures system is

4 assessed. In the context of risk assessment a conservative approach (i.e overestimation of the

5 risk) is typically preferred. The parameters were chosen to maximize the effects of the

6 assumption of single fracture (high diffusion coefficient and low retardation factor) (see Table

7 S1). The numerical model developed in Chambon et al. (2010) is used to simulate the parallel

8 fracture system.

$9 \quad$ Table S1

10 Parameters used in comparison between single and parallel fractures

\begin{tabular}{ll}
\hline Parameters & Single vs. parallel fractures \\
\hline Fracture spacing $2 \mathrm{~B}(\mathrm{~m})$ & variable \\
Fracture aperture $2 \mathrm{~b}(\mu \mathrm{m})$ & 25 \\
Matrix porosity $\phi(-)$ & 0.3 \\
Velocity in fracture $\mathrm{v}_{\mathrm{f}}(\mathrm{m} / \mathrm{y})$ & 2000 \\
Diffusion coefficient in matrix $\mathrm{D}_{\mathrm{m}}\left(\mathrm{m}^{2} / \mathrm{y}\right)$ & $6 \times 10^{-3}$ \\
Retardation factor $\mathrm{R}_{\mathrm{m}}=\mathrm{R}_{\mathrm{f}}$ & 1 \\
Degradation rate $\lambda\left(\mathrm{y}^{-1}\right)$ & $0-0.1$ \\
\hline
\end{tabular}

13 effects for model 1a are lower. The simplification results in underestimating concentration in

14 the fracture for model $1 \mathrm{~b}$, because the storage capacity of the matrix is not finite and the

15 attenuation due to diffusion into the matrix is then higher than for the case of parallel

16 fractures. However the difference between the two systems decreases with increasing fracture

17 spacing and degradation rate. This is illustrated in the example in Fig. S1 using the parameters

18 from Table S1. For a conservative compound, the single fracture model is close to the parallel

19 fractures system for spacing larger than 2 meters, whereas this value decreases to 1 meter for

20 a slow degradable compound $\left(\lambda=0.1 \mathrm{y}^{-1}\right)$. 

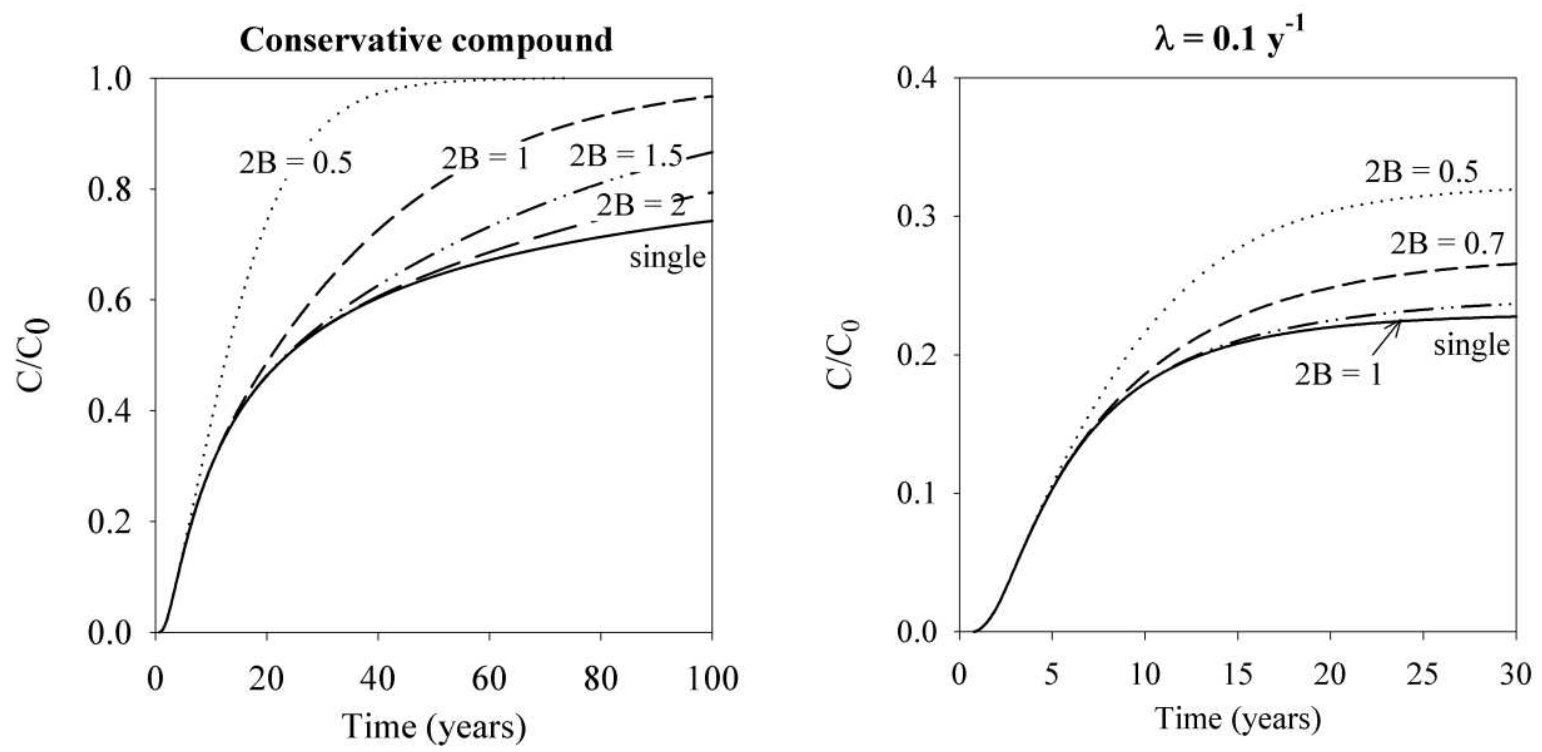

2 Fig. S1. Breakthrough curves of model $1 \mathrm{~b}$ at $\mathrm{z}=5 \mathrm{~m}$ for a conservative $(\lambda=0)$ and a degradable compound $(\lambda=$

$30.1 \mathrm{y}^{-1}$ ), and various fracture spacings. Note different time and concentration scales. Parameters from Table S1.

For conceptual model 2 the effects of the single fracture assumption are illustrated in

6 Fig. S2, which compares the leaching concentration from the risk assessment tool (single

7 fracture) with the numerical solution for various fracture spacings. As for model $1 \mathrm{~b}$, the single

8 fracture model is close to the parallel fractures system for spacing larger than 2 meters,

9 whereas this value decreases to 0.5 meter for a slow degradable compound $\left(\lambda=0.1 \mathrm{y}^{-1}\right)$. The

10 discrepancy between the two systems is due to the continuous supply of contaminant from the

11 infinite matrix in the case of single fracture. The assumption of a single fracture embedded in

12 a semi-infinite matrix results in an overestimation of the contaminant mass discharge to the

13 aquifer, which can then be higher than the initial mass in the system. 

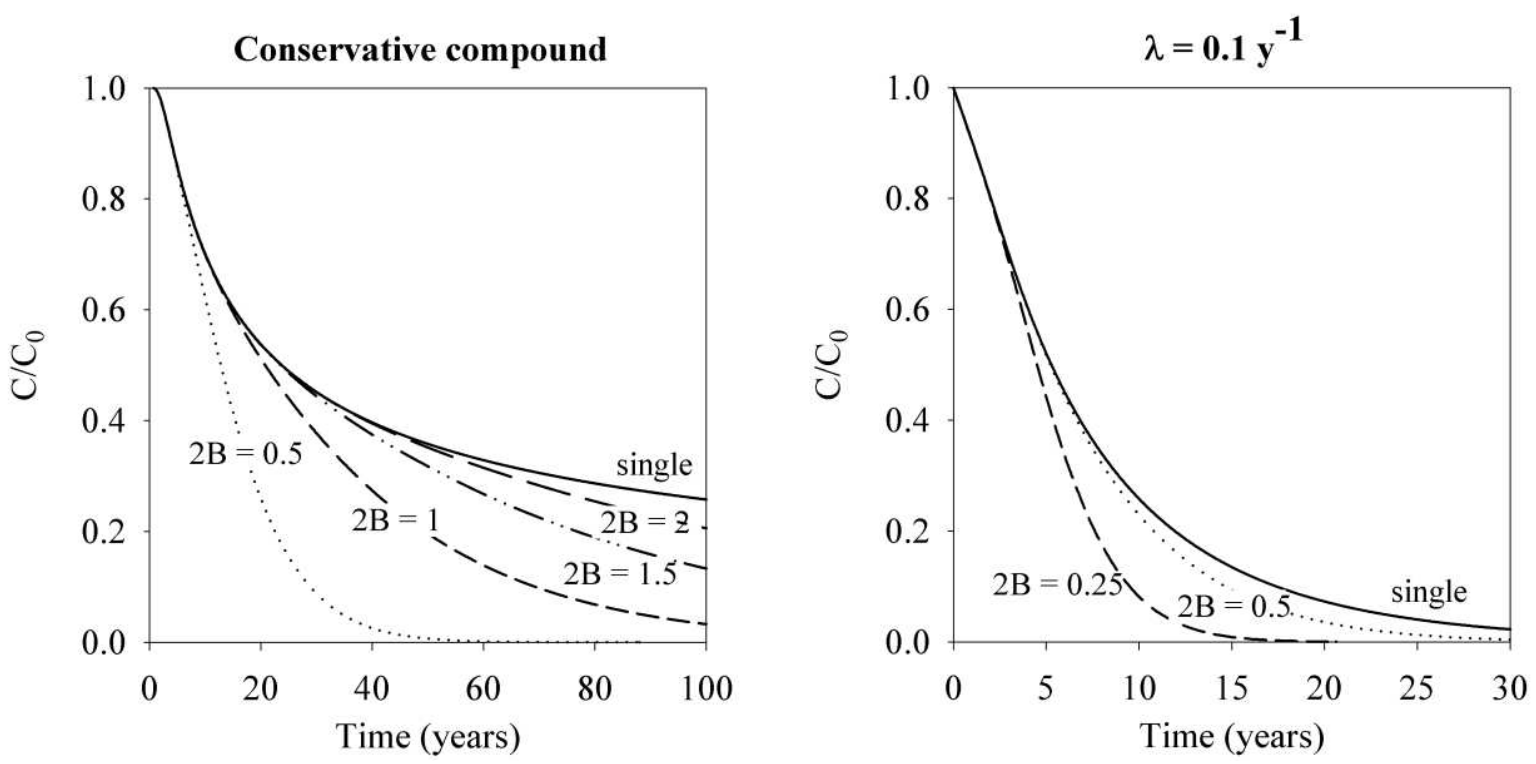

2 Fig. S2. Breakthrough curves of model 2 at $\mathrm{z}=5 \mathrm{~m}$ for a conservative $(\lambda=0)$ and a degradable compound $(\lambda=$

$\left.30.1 \mathrm{y}^{-1}\right)$, and various fracture spacings. Note different time scales. Parameters from Table S1.

4

5

6

7

8

9

10

11

12

13

14

\section{Reference List}

Chambon, J. C., Broholm, M. M., Binning, P. J., and Bjerg, P. L., 2010. Modeling multicomponent transport and enhanced anaerobic dechlorination processes in a single fracture - clay matrix system. Journal of Contaminant Hydrology. 112, 77-90. 